\title{
COMMENTS
}

\section{The Case for Minority Participation in Reverse Discrimination Litigation}

With increasing frequency our nation's courts must consider the charge that race-conscious affirmative action prograins constitute "reverse discrimination." 1 The cases portend the evolution of new and important legal doctrines that will influence race relations more significantly than any doctrinal developinent in equal protection law since Brown v. Board of Education. ${ }^{2}$ Immediately at stake in the reverse discrimination suits is the allocation of thousands of educational, employment, and economic opportunities. Underlying the controversy is the unresolved tension between the ideals of substantive justice and forinal equahity.

Regents of the University of California v. Bakke ${ }^{3}$ represents the mitial attenipt by the United States Supreme Court to grapple with the issue of reverse discrimination. Bakke unfortunately demonstrates that, notwithstanding the importance of the legal issues and the inagnitude of the material stakes involved, the adjudicatory process of reverse discrimination suits is critically flawed. The decision in Bakke is predicated upon a deficiently developed set of facts and legal issues. Most notable is Justice Powell's conclusion that there was no evidence in the record indicating that the defendant medical school had engaged in past discrimination. ${ }^{4}$ This conclusion is pivotal to his analysis distinguishing Bakke from existing authority upholding the use of raceconscious measures to remedy past discrimination. ${ }^{5}$

1. Lexis, as of November 7, 1978, contained approximately 100 published federal cases containing the terms "reverse" or "inverse" "discrimination" and "race."

2. 347 U.S. 483 (1954).

3. 98 S. Ct. 2733 (1978). See also DeFunis v. Odegaard, 416 U.S. 312 (1974) (challenge to preferential admissions program at University of Washington Law School dismissed as moot); McDonald v. Santa Fe Trail Transp. Co., 427 U.S. 273 (1976) (1868 Civil Rights Act held applicable to discrimination against white persons).

4. Id. at $2756-58$.

5. Id. at 2756. "In this case, unlike Lau [v. Nichols, 414 U.S. 563 (1974)] and United Jewish Organizations [, Inc. v. Carey, 403 U.S. 144 (1977)], there lias been no determination by the legislature or a responsible administrative agency that the University engaged in a discriminatory practice requiring remedial efforts." See also Justice Powell's discussion distinguishing employment cases which have upheld the use of benign racial classifications. Id. at 2754-55. 
Justice Powell's finding effectively disregards that Davis medical school's first class, in 1968, contained no blacks, Chicanos, or Native Americans. ${ }^{6}$ Prior to Allan Bakke's first apphication for admission in 1973, only one black and no Chicanos had been admitted through the regular admissions process. ${ }^{7}$ On appeal to the California Supreme Court, amicus groups alleged that the University had enıployed unwritten quotas arbitrarily limiting the number of nonwhite students and that the use of recommendations and interviews in the admissions process prior to the initiation of the minority admissions program had discriminated against minorities. ${ }^{8}$ Moreover, subsequent to trial im that court, evidence surfaced which indicated that in certain instances the school engaged in purposeful discrimination against minority students. $^{9}$ This evidence, coupled with empirical findings of the possible racial and cultural bias of the Medical College Admissions Tests (MCAT), framed a prima facie case of past discrimination by the University. ${ }^{10}$

Justice Powell concludes that there was no evidence that the quantitative factors considered by the medical school (e.g., MCAT scores) are culturally biased or that the school's mmority admissions prograin

6. Id. at 2739 .

7. Id. at 2741 n.6. Two chicanos were admitted in 1973, and four in 1974, through the regular admissions program.

8. Petition of the NAACP for leave to file Amicus Curiae on Petition for Rehearing and Brief before the California Supreme Court. See Lawrence, When the Defendants Are Foxes Too: The Need for Intervention by Minorities in "Reverse Discrimination" Suits Like Bakke, 34 GuILD PRACTIONER I (1976).

9. Professor Paul Goodman, president of the U.C. Davis Faculty Union, asserted in a letter to the Regents that personal interviews revealed that blacks were systematically diverted from regular admissions to the special adınissions program regardless of their credentials, that black students were being subjected to racial slurs, discriminatory grading and disciplinary ineasures, and that the University falsified mmority admissions statistics by counting black foreign students from Africa for purposes of affirmative action reporting. Daily Californian, Feb. 17, 1978, at 8, col. 4.

10. The Bakke decision effectively ignored the hotly contested debate over whether the Medical College Admissions Test (MCAT) has a discriminatory inpact and bias. An extensive survey of available enpirical evidence on the issue was presented in several anicus briefs in Bakke. See Brief of the Black Law Students Association, Berkeley School of Law, as Amicus Curiae. That evidence demonstrates that the MCAT has a substantial racially disparate inpact, see, e.g., Feitz, The MCAT and Success IN Medical School (1974); Johnson, Smith \& Tarnoff, Recruitment and Progress of Minority Medical School Entrants, 1970-1972, 50 J. MED. EDuc. 713, 755 (1975), but little relation to clinical performance in medical school, see Richards, Taylor \& Price, The Prediction of Medical Intern Performance, 46 J. APPL. PsYCH. 142 (1962), or in practice as a physician, see Turner, Helper \& Kriska, Predictors of Clinical Performance, $49 \mathrm{~J}$. MED. EDuc. 338 (1974). One study provided specific evidence that the gap between the MCAT scores of minority and white candidates is considerably wider than the gap between their performances in medical school. See Simon \& Covell, Performance of Medical Students Admitted Via Regular and Admission-Variance Routes, 50 J. MED. EDuc. 237 (1975). Moreover, another study revealed that the average MCAT score of blacks who successfully conpleted the first two years of medical school was lower than that of whites who were unable to coinplete thein. See FeITz, supra. 
was formulated to correct for any such biases. ${ }^{11}$ This finding is crucial to the decision reached in Bakke. If the bias of the numerical criteria were estabhished, ${ }^{12}$ the University's mmority admissions program could be justified as a program to cure established inaccuracies in predicting academic performance. It might be argued that such a program affords no "preference" at all. ${ }^{13}$

It is clear why these issues were not explored by either the California $^{14}$ or the United States Supreme Courts. The University could not admit to past discriminatory practices or the inaccuracy of its numerical admission criteria without mviting suits from (1) minority applicants rejected prior to the institution of the minority admissions program, (2) those rejected during the program's existence but who contend that the special admissions policy was not sufficient to compensate for the biased criteria, (3) those who contend that the proper reinedy is the development of a nonbiased unitary admissions policy rather than the stigmatizing minority admissions program, and (4) other apphicants possibly affected by the biased criteria but not accorded preferential treatunent (for exainple, Asian Americans, poor whites, and other "disadvantaged" individuals where they are not included in the special admissions program).

Moreover, the University could not admit maccuracy and bias in its selection procedure for the purpose of defending Bakke's challenge without placing itself in a precarious administrative position. If the University were to lose the case, so that the ininority admissions prograin would have to be abolished, the school would be forced to rely on admittedly defective criteria as the basis for its admissions decisions. In order to avoid future lawsuits from minorities, the defendant would be forced to develop new admissions criteria, thereby incurring substantial administrative costs. The problem is especially acute with professional schools where the number of applicants far exceeds the number of available admissions places. If the affirmative action program were sustained solely on the basis of admittedly biased criteria, the University could not adopt different criteria without jeopardizing the supporting rationale for the special program (i.e., compensating for

11. 98 S. Ct. at 2757 n.43. Significantly, Justice Powell's opinion in Bakke noted that "[n]othing in this record-as opposed to some of the general literature cited by Mr. Justice Brennan . . . - even remotely suggests that the disparate inpact of the general admissions prograin at Davis Medical School . . . is without educational justification." $98 \mathrm{~S}$. Ct. $2758 \mathrm{n} .44$ (emphasis added).

12. See note 10 supra.

13. $98 \mathrm{~S}$. Ct. at $2757 \mathrm{n} .43$.

14. Concluding that no past discrimination was shown, Justice Mosk's opinion for the California Supreme Court stated: "Admittedly, neither the University nor Bakke would have an interest in raising such a claim. But this fact alone would not justify us in making a finding on a factual matter presented below." 18 Cal. 3d 34, 60 n.29, 553 P.2d 1152, 1169 n.29, 132 Cal. Rptr. 680, 697 n.29 (1976). 
the biased admission criteria). In order to preserve its flexibility with respect to adnissions policies and criteria, the University would prefer to justify the affirmative action prograni on other bases (e.g., the need to promote diversity in the student body or the desirability of increasing inedical services to minority communities).

Bakke is not the only case in which these types of tensions have been created. In Weber v. Kaiser Aluminum \& Chemical Corp. ${ }^{15}$ a reverse discrimination action involving employment, no prior discrimination by defendant Kaiser was found, despite evidence which could have established a prima facie violation of Title VII. ${ }^{16}$ The majority relied on this tenuous factual finding ${ }^{17}$ and declared Kaiser's voluntarily impleinented racial quota for selection to an on-the-job traming prograin invalid under Title VII. Just as with Bakke, the parties in Weber had no incentive to raise all pertinent issues or to explore fully those issues that were raised. ${ }^{18}$ Persons who were directly affected by the decision and who would have been in a position to raise these issues-the beneficiaries of the affirmative action prograin-had no input at the trial.

Bakke and Weber deinonstrate that important facts and analysis of relevant legal issues may be developed madequately by the parties to reverse discrimination lawsuits. The implications for the integrity of the adjudicatory process and for fairness to the rights and interests of absentee affirmative-action beneficiaries ${ }^{19}$ are obviously significant.

15. 563 F.2d 216 (5th Cir. 1977), cert. granted, 47 U.S.L.W. 3408 (Dec. 11, 1978).

16. 563 F.2d at 231-33. There was a substantial underrepresentation of blacks in the defendant's unskilled work force (14.8\% of total) compared to the composition of the area workforce (39\%). The defendant required that employees have prior experience in the craft to entcr a limited traming program in which only two of the 28 trainees were black.

17. Id. at 224.

18. Judge Wisdoin in his dissent sharply criticized the basis of the majority's factual finding: In spite of the district court's finding that the defendants had not discriminated against blacks at Gramercy, there were arguable violations. The district court made its finding on the basis of testimony from two Kaiser personnel officials. The defendants werc never required to rebut a prima facie case, proved statistically, because the statistics were never analyzed by the district court. The reason for the lack of analysis is clear: no hitigant wanted to see past discrimination found. The plaintiffs knew it would wcaken their case. Kaiser and the Union could only admit past discrimmation by strongly inviting private suits by blacks. Although the trial below was in no way collusive, the defendants could well have realized that a victory at the cost of admitting past discrinination would be a Pyrrhic victory at best. In the district court no one represented the separate interests of the minority employees of Kaiser, the only people potentially interestcd in showing past discrimination. It is not surprising, therefore, that no party fully analyzed the facts within the context of Title VII. Such an analysis would show thrce possible or probable violations.

Id. at 231 .

19. The concept of "beneficiaries of affirmative action prograins" is inherently amorphous and uncertain. There are a number of persons who have a stake in reverse discrimination lawsuits. Certainly included are those ininority-group inembers substantially affected by the operation of such programs (e.g., medical school applicants, or residents of currently undcrserved minority communities). White inedical students could argue that they benefit from a inulticultural 
This Comment argues that this serious problem must be remedied by affording beneficiaries of the programs and policies challenged in reverse discrimination suits full participation in all stages of the litigation. Following an analysis of the theoretical justifications for such participation, existing methods for accomplishing this goal will be exammed. The primary focus will be upon intervention as of right under Federal Rule of Court Procedure 24(a) as the most feasible procedural device for assuring beneficiary participation according to the theoretical justifications for such participation. The Comment will also examine the apphication of the indispensable party doctrine of rule 19(a).

I

THEORETICAL JUSTIFICATIONS FOR BENEFICIARY PARTICIPATION

There are three justifications for allowing minority beneficiaries of affirmative action programs to participate in reverse discrimination litigation. The first is a jurisprudential policy of safeguarding the integrity and effectiveness of the adjudicatory process by assuring full consideration of all relevant facts and issues. The second is the need to provide fairness and due process to those beneficiaries who have a substantial interest in the litigation coupled with the recognition that such fairness can only be achieved when the persons directly affected are adequately represented. The third is the notion that mimority participation in reverse discrimination lawsuits is doctrinally consistent with existing theories of interest representation.

\section{A. Preserving the Integrity of the Adjudicatory Process}

The failure to litigate the issues of the defendants' past discrimination or biased selection methods in Bakke and Weber was the inevitable result of the interplay between substantive legal doctrines and the defendants' parochial interests. The cases demonstrate that the assumptions underlying the traditional adversary nodel of litigation are niapposite in the reverse discrimination context. The adversary systen presupposes that two parties representing dramatically opposite interests will litigate all relevant facts and legal issues. ${ }^{20}$ But in reverse dis-

educational environment. Cf. Trafficante v. Metropolitan Life Ins. Co., 409 U.S. 205 (1972). There is also a set of ideological interests unifying those of all races who favor the use of raceconscious remedial measures. But the term "beneficiaries" used throughout this Comment refers to the intended and primary beneficiaries-the first group-who ideologically support affirmative action. This group has both a substantial, identifiable, and legally recognizable interest and is not adequately represented by either party in the litigation.

20. See generally F. James \& G. Hazard, Civil Procedure $\$ \S 1.2,10.19$ (2d ed. 1977); Shapiro, Some Thoughts on Intervention Before Courts, Agencies, and Arbitrators, 81 HaRv. L. REv. 721 (1968).

The analysis undertaken in this Comment of the deficient development of factual issues in 
crimination suits there are three distinct sets of interests and viewpoints-those of (1) the plaintiff challenging the legality of the affirmative action prograin, (2) the defendant adıninistering or enforcing the prograin, and (3) the prograin's beneficiaries. While the defendant and the beneficiaries both inay desire to maintain the affirmative action prograin, their interests are not congruent. And even where their interests' are substantively sinuilar, their divergent perspectives may cause them to place different emphasis on short-terun versus long-terin goals. These different preferences could greatly influence the fashioning of the defense to the reverse discrimination charge.

There are several reasons why the administrators of an affirmative action prograin cannot be trusted to represent the interests of the prograin's beneficiaries. First, there is the substantial possibility of a difference between the defendant and the beneficiaries in the intensity of their interests in the prograin. Conceivably, a defendant inay be weakly committed to or even hostile to its own program. This possibility cannot be discounted; many such prograins have been established by unwilling einployers and universities through legal coercion. ${ }^{21}$ Even ostensibly voluntary programs nay have been the result of political pressure. In Bakke, the University argued in teruns of "voluntary" affurmative action programs, but student strikes and community and political pressures lay behmd the establishment of inany affirinative

Bakke and Weber conservatively presumes the legal positivist viewpoint that the courts analytically divine legal principles and then apply them to the facts at bar. But the factual posture of a particular case in casting the relative equities of the parties may not only be determinative of the disposition of a case, but may influence the legal analysis and principles adopted by the court. For example, were an intervenor successful in establishing significant culpability on the reverse discrimination defendant's part, a court unight be more inclined to hold that a minimal showing of past discrimination, less exacting than a statutory or constitutional violation, might suffice to validate the challenged affirmative action program. To the extent that this legal realist theory has enpirical merit, beneficiary participation is even more strongly compelled since a variance in the factual record might produce a different mode of legal analysis and precedential ramifications.

21. Two inajor reverse discrimination cases reaching the federal courts of appeals, Weber v. Kaiser Aluminum \& Chem. Corp., 563 F.2d 216 (5th Cir. 1977), cert. granted, 47 U.S.L.W. 3408 (Dec. 11, 1978), and EEOC v. AT\&T, 506 F.2d 735 (3d Cir. 1974), mvolve situations in which the employers adopted affirmative action programs in the face of legal pressure from minorities and governmental agencies. In Weber, the court noted that the district court found that the 1974 collective bargaming agreement establishing the contested affirmative action program "reflected less of a decision on Kaiser's part to train black craft workers than a self-interest in satisfying the OFCC in order to retain lucrative governmental contracts [under Executive Order 11246 mandating affirmative action by government contractors]." $563 \mathrm{~F} .2 \mathrm{~d}$ at 226 . The court also stated that "this collective bargaining agreement [providing for the challenged affirmative action program] was entered into to avoid future hitigation and to comply with the threats of the Office of Federal Contract Compliance Programs (OFCC) conditioning federal contracts on appropriate affirmative action." Id. at 218.

The affirmative action program challenged in $E E O C$ v. $A T \& T$ was a result of a consent decree approved by the court after a complaint was filed by the EEOC (Equal Employment Opportunity Council) charging defendants with violation of the Fair Labor Standards Act, Title VIl, and Executive Order 11246. 506 F.2d at 737. 
action programs. ${ }^{22}$ Where race-conscious programs have such origins, the defendant's commitment to its position is suspect. It is not inconceivable that the defendant in those circumstances might actually invite suits charging reverse discrimination in order to safely rid itself of the undesired affirmative action program, ${ }^{23}$ and it is certainly a real possibility that a less than vigorous defense will be put forth.

Second, the defendant's and beneficiaries' interests are incongruent because, as a general matter, the beneficiaries' parainount concern is witl preserving meaningful minority representation in the defendant's workforce or student body. In contrast, the primcipal concern of the employer or university may be to obtain a clear decision as to the legality of its affirmative action program so as to minimize future litigation and to facilitate planning with respect to admissions or hiring policy. ${ }^{24}$ A clear decision is especially valuable to the defendant caught in a potential legal scissors-liability to minorities for "forward" discrimination absent a remedial program on one side and liability to whites for reverse discrimination in connection with a special program on the other. $^{25}$ For administrative reasons the defendant prefers a clear adverse decision to an ambiguous favorable one since any clear decision will ininimize the danger of future lawsuits fron both whites and ininorities.

Moreover, the defendant's institutional interests dictate the presentation of a defense that may be adverse to the interests of minority beneficiaries; as previously discussed, the defendant is unlikely to raise the inportant defenses of past discrimination ${ }^{26}$ or biased selection cri-

22. The special admissions program at the University of California Medical Scliool at San Francisco was established after an intensive strike by minority service employees at the school protesting the lack of mimority representation in the student body there. Synapse (school newspaper), May 25, 1978, at 1, col. 1 .

Differences over the continuation and administration of mimority programs between uninority students and school officials are by no uneans unknown. Within the last year, the faculties at UCLA, Hastings, and University of San Francisco Law School lave contemplated major clianges in the structure of their minority admissions programs. In each instance, these proposals were met with vigorous student and community opposition. In one case, the controversy culminated in a strike and physical confrontation with the police. S.F. Examiner, Marcl 4, 1978, at 1, col. 2. See Jennings, The Struggle to Survive: A Case Study of Repression Against Minority Students at Wayne State University Law School, in AfFIRMATIVE ACTION IN CRISIS: A HaNDBook for Activists (National Lawyer's Guild and the National Conference of Black Lawyers eds. 1977); Asian American Law Students' Association, Report of the Boalt Hall Asian American Special Admissions Research Project, 5 Amerasia J. 21 (1978).

23. See notes 113-16 and accompanying text infra.

24. See Anicus Brief, Deans of the Univ. of Cal. Law Scliools, Regents of the Univ. of Cal. v. Bakke, 98 S. C.t. 2733 (1978).

25. The paradox of the past discrimination doctrine adopted in Bakke by Justice Powell and in Weber is aptly described as a "high tightrope without a net" by Judge Wisdom in Weber, 563 F.2d at 230 (Wisdom, J., dissenting).

26. Intervention is particularly important under Justice Powell's analysis in Bakke since absent an adjudication of the issue, even an admission by the reverse discrimination defendant 
teria. $^{27}$

might not suffice to validate an affirmative action program given his intimation that a single university or employer is not a sufficiently competent body to make the requisitc determination of past discrimmation.

It should be noted that the importance of a particular institution's past discriminatory practice has not been definitively settled. Only five of the Supreme Court Justices (Powell, Brennan, White, Marshall, and Blackmun) reached the constitutional question in Bakke, and, of those, four would apparently not require a finding of past illegal discrimination on the University's part in order to hold benign racial preference legal. The opinion of Justices Brennan, White, Marshall, and Blackmun would require only that it is reasonable to conclude that the failure of minorities to quahfy for admissions under regular procedures was due primcipally to the effects of past societal discrimination generally. They conclude:

[W]hile we agree [with Mr. Justice Powell] that reversal in this case would follow $a$

fortiori had Davis been guilty of mvidious racial discrimination or if a federal statute inandated that universities refram from applying any admissions pohcy that had a disparate and unjustified racial impact .... we do not think it of constitutional significance that Davis had not been so adjudged.

$98 \mathrm{~S}$. Ct. at $2787-88$ n. 42.

Even if the Brennan view eventually prevails, however, the issue may not become entirely irrelevant. The extent of judicial deference given to an einployer's or school's affirmative action program inay well depend upon a specific finding of past discrimination. It is fairly well cstablished that more extreme race-conscious remedies will be upheld where there has been a judicial finding or legislative or administrative determination of past discrimination. United Jewish Organizations v. Carey, 430 U.S. 144 (1977); Franks v. Bowman Transp. Co., 424 U.S. 747 (1976); Albemarle Paper Co. v. Moody, 422 U.S. 405 (1975); Swann v. Charlotte-Mccklenberg Bd. of Educ., 402 U.S. I (1971); Contractors Ass'n of E. Pa. v. Secretary of Labor, 442 F.2d 159 (3rd Cir. 1971), cert. denied, 404 U.S. 854 (1971). It is conceivable that, in the absence of any such dctermination of past discrimmation, the courts will afford less remedial freedom to einployers and schools in formulating their affirmative action policies since the state mterest in vindicating the legal nondiscrimination rights of mimorities would be lacking. Furthermore, a judicial or legislative finding of past discrimination will safeguard against abuse and disregard of the individual rights of members of the burdened (nonmmority) class in the formulation of race-conscious remedies. Where the individual school or einployer embarks on its own initiative in prescribing an unsupervised affirmative action program, that program should be subject to closer judicial scrutiny. Moreover, where there has been a governmental finding of discrimination and prescription of remedies, it can be said that, at least theoretically, society, effectively expressing itself through the actions of the court or legislature, has made a collective decision in a politically prescribed forum adjusting the rights of the various burdened and benefited parties involved. See $98 \mathrm{~S}$. Ct. at 2757-59.

Moreover, even under the holding of the Brennan group in Bakke, in the absence of proven past discrimination on the defendant's part, the defendant would appear to have the burden of demonstratimg pervasive past societal discrimination against the particular groups given preferential treatinent and that such discrimmation was the primcipal cause behind the disparate impact of its admissions policies. $98 \mathrm{~S}$. Ct. at 2787. While the standard of meeting that burden is left unclear as the Brennan opinion merely held, ad hoc, that it had been met in Bakke, id, a specific finding of defeudant's past discrimination would obviate the necessity of demonstrating the causahty apparently required by Justice Brennan. Hence, the issue of specific past discrimination, while rendered less significant, would still be relevant.

Even if the issue of past discrimination on the defendant's part were to become constitutionally irrelevant, there is no assurance that it will cease to play an important role in statutory reverse discrimination cases. Since the legislature may prohibit even what the Constitution permits, it is conceivable that the Weber holding-that under Title VII prior discrimination must be demonstrated before affirmative action quotas inay be used-might eventually be adopted by the Supreme Court. If such were the case, the defendant's previous conduct would remain a key factual element in similar Title VII cases.

27. It slould be noted that the University of California made a passing reference to the fact 
Finally, there is a substantial disparity between the defendant's and beneficiaries' interests with respect to the question of the degree of institutional autonomy that the courts should afford universities and employers. An important point pursued by the University in Bakke, for example, was the need to preserve the academic freedom of schools and universities by avoiding excessive judicial intervention. ${ }^{28}$ While a policy of judicial deference would serve the interests of the University, it would make it more difficult for minorities to sue educational institutions practicing invidious or "forward" discrimination.

The same arguments apply in employinent contexts where the defendant employer might argue that the courts ought to refrain from involving themselves in the conduct of business inanagement and personnel pohcy. Where the defendant is a local government agency, it would argue that federalisin requires state and local autonony and freedoin to experiment. In either case, judicial affirmance of the advocated principle, while furthering the defendant's institutional interests, likely would disadvantage minorities in forward discrimination suits.

The general tension between the viewpoints of the defendants and the beneficiaries is manifest with respect to particular issues. For instance, it might be argued that a particular affirmative action program is not inerely legally permissible, but in fact is legally compelled. Such an argument would be predicated on the assertion that but for the affirmative action program, the defendant's regular selection process or unredressed past discrimination would violate the Constitution or an antidiscrimination statute or regulation. In Bakke, for example, it could have been argued that the underrepresentation of minorities in the Davis student body constituted a violation of the fourteenth

that "[m]any schools recognized that a further step toward tempered reliance on numerical indicators [was prudent], particularly in light of concerns about their accuracy in the case of historically alienated minorities ...." Brief for Petitioner at 31. This was hardly sufficient, however, to constitute the raising of a legal issue; Justice Powell in lypothesizing an additional state purpose in using racial classifications-fair appraisal of eacl apphicant's academic promise in the light of some cultural bias-found that the University liad failed to articulate such a purpose. $98 \mathrm{~S}$. Ct. at 2758.

28. In his rebuttal argument before the Supreme Court, Archibald Cox in belialf of the University stated:

[W] urge that this court slould not get the lower federal courts into being the supervisors of the admissions policies of certainly state and perliaps private institutions . . . . [T]he judicializing or constitutionalizing, the drawing of courts in, the writing of monohithic rules, tends to dampen one of the greatest-abandon one of the greatest sources of creativity in this country....

Transcript of Oral Arguments 80-81 (Oct. 12, 1977). The value of this academic freedom was recognized by Justice Powell in his evaluation of the state interest in the University's attainment of a diverse student body, $98 \mathrm{~S}$. Ct. at 2760-61, and by Justice Blackmun's general willingness to defer to the educational judgments of the University in his statenent that "[t]le administration and management of educational institutions are beyond the competence of judges and are within the special competence of educators ...." $98 \mathrm{~S}$. Ct. at 2807. 
amendment that could be remedied only by the affirmative action program. ${ }^{29}$ The University of California, of course, never argued the point. Given the original congressional concern with the racial segregation of schools receiving federal funds, ${ }^{30}$ the University also could have contended that Title VI inandated an affirmative action program. ${ }^{31}$ Instead, it took the position that the substantive reach of Title VI is coextensive with the fourteenth amendment. Regardless of whether the University's position reflected an untainted judgment on the inerits of competing interpretations of Title VI, it is evident that the position comports with its interest in minimizing the scope of legal restrictions upon its admissions decisions. A judicial determmation that the prograin was required by Title VI would prevent the defendant froin dismantling it at a future date, a result inconsistent with the defendant's goal of maximizing its institutional freedom..$^{32}$

The University's assertion in Bakke that no private right of action exists under Title VI further illustrates the tension between the viewpoints. Although successful assertion of the argument would have barred Bakke's Title VI claim, ininority beneficiaries might prefer that the court find a private right of action under Title VI. Such a finding would facilitate future discrimination actions by inmorities against institutions receiving federal funds. ${ }^{33}$

29. The norm established in Washington v. Davis, 426 U.S. 229 (1976), requiring discriminatory intent as an essential element of unconstitutional de facto discrimination makes the task of demonstrating that affirmative action is constitutionally compelled virtually impossible to meet. (Indeed, in Washington the court significantly noted that the employer-defendant had instituted minority recruitment efforts, and this seemed to have sufficed in repudiating the inference of invidious intent. Id. at 246.) The Bakke majority apparently held that the substantive scope of Title VI is identical with that of the fourteenth amendment, in which case the task is no easier with respect to that statutory cause of action. However, Lau v. Nichols, 414 U.S. 563 (1974), which held that Title VI may require race-conscious remedial measures even when past practices did not constitute a constitutional violation, has not been explicitly overruled. Presumably the applicability of the Griggs v. Duke Power Co., 401 U.S. 424 (1971), test under Title VIl, which allows a plaintiff to make a prima facie case of discrimination by a mere showing of disparate impact, eases the burden faced by mimority beneficiaries in employment cases.

30. See $98 \mathrm{~S}$. Ct. at 2768-82 (Brennan, J., concurring and dissenting).

31. For instance, it could have been argued that the disparate impact of the University's regular admissions process inpact established at least a prima facie case of Title VI violation, perhaps similar to the Title VII standard. See Griggs v. Duke Power Co., 401 U.S. 424 (1971).

32. The argument that preferential treatment is legally compelled may be especially valuable to potential beneficiaries where minority groups are unable to muster political and economic power sufficient to dissuade an employer or school from dismantling an affirmative action program in the face of contimumg litigation or general public opposition. Precedential establishment of such an "entitlement" would also assist minority interest groups in pressuring other employers and universities who have sinilar histories and selection processes but who do not have a preferential program into implementing affirmative action policies.

33. Similarly, when the reverse discrimination defendant is not a public institution, such as a private university, it might assert as a defense to a constitutional equal protection attack that its conduct does not constitute "state action." Yet, the applicability of the equal protection clause or the existence of a statutory private right of action may be crucial to minorities who are still sorely underrepresented in higher education, notwithstanding the existence of affirmative action programs. See generally National Board on Graduate Education, Minority Group Partici- 
Similarly, the argument could be asserted by the defendant that the reverse discrimination plaintiff would not have been admitted even in the absence of the challenged affirmative action program and therefore lacked standing under article III of the Constitution. ${ }^{34}$ The defendant has an important interest in raising the standing issue since by making it difficult generally for plaintiffs to sue on a discrimmation claim, the defendant minimizes private lawsuits and thereby enhances institutional discretion. In contrast, while it would be in the immediate interest of minorities to challenge the nonminority plaintiff's standing in the reverse discrimination suit, such a defensive shield easily could be turned against them in future litigation where minority applicants are suing the university for forward discrimination. ${ }^{35}$

Pation in Graduate Education (1976); E. El-Khwanas \& J. Kinzer, Enrollment of Minority Graduate Students at Ph.D. Granting Institutions, Higher Educational Panel Reports, No. 19 (1974).

34. See Warth v. Seldin, 422 U.S. 490 (1975). In Bakke, the plaintiffs standing conceivably could have been challenged on other grounds as well. For instance, surrounding Bakke's challenge to the Davis special adinissions prograin was a controversy pertaining to the special discretionary admissions on the Dean's part of the sons and daughters of influential and wealthy families. See L.A. Times, July 5, 1976, § 2, at 1, col. 1; id, July 14, 1976, § 2, at 1, col. 2. The argument could be made that such practices were so extensive that even in the absence of the special admissions program, Bakke would not have been admitted. Similarly, it could have been contended that discrimimation on the basis of age was the actual cause of Bakke's denial of admissions.

35. The University did not raise the standing issue, but several amici did. This reversal of the expected postures is not surprising. The University may have wanted a ruling as to the propriety of its admissions program, and raising a standing issue would only defer obtaining legal clarification. Minority groups, on the other hand, in perceiving the weakness of the record established at the trial court, and the inportance of the case as the first attempt of the Supreme Court to address the issue of reverse discrimination, may have preferred that the Court, rather than reaching the merits and rendering an adverse decision, await a stronger case. In any event, Justice Powell rejected the amici's contention that Bakke lacked standing, characterizing his asserted constitutional injury as not being able to compete for all 100 places in the class, simply because of his race, not the fact of being denied admission he otherwise would have had. $98 \mathrm{~S}$. Ct. at $2743 \mathrm{n} .14$.

The standing issue was not addressed by the other Justices. The University effectively waived the standing issue both by conceding its inability to demonstrate that Bakke would not have been admitted even in the absence of the special adinissions program and by filing a cross-clain for declaratory judgment at the trial court level.

It is conceivable that Justice Powell's holding might be overturned in a subsequent suit in which the standing issue is addressed by the entire Court. It certainly could be argued that the "injury" that must be demonstrated is the actual denial of admissions due to the plaintiffs race. This characterization of the requisite injury (as opposed to merely not being able to compete for all 100 places in the class because of the plaimtiff's race) would seen to comport with the reasoning of Warth v. Seldin, 422 U.S. 490 (1975) and Simon v. Eastern Ky. Welfare Rights Organization, 426 U.S. 26 (1976), which required a causal link between the asserted substantive mjury and the effectiveness of the rehief sought. In the latter case, the Court noted "[i]t is equally speculative whether the desired exercise of the court's remedial powers in this suit would result in the availability to respondents of such hospital services" as were putatively denied them as a result of the defendant's conduct. $I d$. at 43 . Since the potential effectiveness of the court's rehef is an important consideration in the standing analysis, Justice Powell's disposing of the issue by stating "[t] he question of respondent's admission vel non is merely one of relief," $98 \mathrm{~S}$. Ct. at $2743-44 \mathrm{n}$. 14 , is unconvincing. Such a standing argument, of course, presumes that Warth and Simon were correctly decided. See Instice Bremıan's dissent in Warth, 422 U.S. at 519 (Brennan, J., dissenting). 
It is evident, then, that there are three distinct viewpoints that inust be contended with in the reverse discrimination lawsuit. Failure to permit participation by the program's beneficiaries will result in a total failure to analyze important issues that neither the plaintiff nor the defendant is likely to raise. The integrity of the judicial process, dependent upon vigorous advocacy and the full litigation of all relevant issues, is surely impaired in the absence of sucli third party participation.

\section{B. Fairness to Minority Beneficiaries}

The need for minority participation in reverse discrimination suits is even inore apparent when the important nature of the interests which they would assert, and which otherwise iniglit go unprotected, ${ }^{36}$ is considered. Those interests may achieve the status of a constitutional or statutory "rigltt" or they may be based on a "privilege" conferred by a voluntarily instituted but noncoinpelled affirmative action program. ${ }^{37}$ In eitlier event, the interests are so substantial that they should not be jeopardized in litigation where tlie ininorities asserting the interests have no effective opportunity to be heard.

One interest of the beneficiaries is the protection of their material stake in the affirmative action program, i.e., admission to an educational institution, financial aid, employment, or public works contracts. This interest is identical to that of the plaintiff challenging the affirmative action program. In addition, minority beneficiaries have extensive secondary or derivative interests. For instance, in Bakke the interest of minority groups in the minority admissions program included the improveinent and expansion of inedical services in minority commumities, the provision of role models for minority youth, and increased representation of minority groups in educational institutions and professions to enhance professional awareness of and sensitivity to the particular needs and problems of minority communities. ${ }^{38}$ Similarly, in employ-

\footnotetext{
It is noteworthy, however, that notwithstanding Justice Powell's rejection of anici's standing argument, the opinion of Justice Stevens in Bakke, if narrowly read, may lend significance to the but-for causation analysis. In ruling for Bakke, Justice Stevens held that the prohibitive language of Title VI had to be applied literally and that, since the University adinittcd it was unable to carry its burden of demonstrating that Bakke would not have been adinitted even in the absence of the ininority program, Bakke was "excluded froin participation" in the inedical school program. $98 \mathrm{~S}$. Ct. at 2810-11. Arguably, had the University successfully challenged the causal nexus between Bakke's denial of adunission and the existence of the special admissions prograin, there would have been no "exclusion" on the basis of race and hence statutory relief would not have been granted.

36. See text accoinpanying and notes 21-27 supra.

37. The right/privilege distinction has lost inuch of its independent constitutional signifcance. See generally Van Alstyne, The Demise of the Right-Privilege Distinction in Constitutional Law, 81 HaRv. L. REv. 1439 (1968).
}

38. See $98 \mathrm{~S}$. Ct. at $2756-60$. 
ment and public works "set aside" cases, ${ }^{39}$ economic conditions im minority communities-including uneinployinent rates and capital growtl and formation-may be vitally affected. Where affirmative action in the employment of police persomel is involved, ${ }^{40}$ members of minority communities stand to benefit froin racial integration of the police force. Sucl integration would reduce racist enforcement of the law, police brutality, and language and cultural barriers, thereby facilitating improved police-community relations generally. In cases concerning affirmative action in the employment of correctional officers in prisons, ${ }^{41}$ mmority prisoners liave an interest in an integrated staff whiclı can ameliorate racial tension, violence, and brutality.

It is evident that minority beneficiaries stand to bear a substantial and concrete material loss when a decision favors a reverse discrimination plaintiff. That potential inaterial loss is as substantial as the plaimtiff's and possibly more extensive than the defendant's. Because the beneficiaries' interests are not adequately represented in the litigation, beneficiaries will suffer their loss witlout an effective opportunity to be lieard. Due process riglts of the beneficiaries niay well be implicated, whether the deprivation concerns a constitutional right, a statutory entitlement, or a mere "privilege."

Where the reverse discrimination defendant is guilty of committimg past discrimination or utilizimg a discriminatory selection process, the beneficiaries' entitlement to "preferential treatment" under the challenged program attaches as a legal right. ${ }^{42}$ Under these circumstances the affirmative action program nay be constitutionally compelled. Where the defendant's past conduct violates an antidiscrimination statute, mmority beneficiaries liave a "legitimate claim of entitlement" 43 to have their applications considered in a remedial, raceconscious program. ${ }^{44}$ Where the affirmative action program is instituted witlout constitutional or statutory compulsion, the beneficiaries' interest is predicated upon the discretion of the defendant institution and therefore may be labeled a mere 'privilege.'

39. See, e.g., Montana Contractors' Ass'n v. Secretary of Commerce, 439 F. Supp. 1331 (D. Mont. 1977). See also Associated Geu. Contractors v. San Francisco Unificd School Dist., 431 F. Supp. 854 (N.D. Cal. 1977); Associated Gen. Contractors v. Secretary of Commerce, 441 F. Supp. 955 (C.D. Cal. 1977); Contractors' Ass'n v. Kreps, 441 F. Supp. 936 (W.D. Pa. 1977). See generally note 50 infra.

40. See, e.g., Chicano Police Officers Ass'n v. Stover, 526 F.2d 431 (10th Cir. 1975), vacated on other grounds, 426 U.S. 944 (1976). But see Detroit Police Officers Ass'n v. Young, 446 F.Supp. 979, 1014 (E.D. Mich. 1978). See also Baker v. City of Saint Petersburg, 400 F.2d 294, 301 n. 10 (5th Cir. 1968). See generally Report of the National Advisory Commission on Civil DisORDERS 165-66 (1968).

41. See Wright v. Enimoto, No. 73-1422 (N.D. Cal., filed Aug. 15, 1973).

42. See Swann v. Charlottc-Mecklenburg Bd. of Educ., 402 U.S. 1 (1971).

43. Board of Regents v. Rotl, 408 U.S. 564 (1972).

44. Albemarle Paper Co. v. Moody, 422 U.S. 405 (1975). 
Where either a constitutionally based "legal right" or a statutory "entitlement" is endangered by reverse discrimination litigation, due process requires that the minority beneficiaries be afforded participation rights. ${ }^{45}$ Even where a mere "privilege" is at stake the interest is substantial enough to deserve certain procedural due process protections. ${ }^{46}$ For instance, if the legislature enacted an affirmative action statute and an adininistrative agency promulgated regulations thereunder requiring state universities to implement special admissions prograins, minority beneficiaries would have standing to sue to enjoin any violation by universities thereunder. ${ }^{47}$ And if the administrative agency itself failed to enforce its regulations against the universities, beneficiaries could also bring suit to enjoin such nonenforcement. ${ }^{48}$

Adinittedly, where preferential treatment is merely a "privilege," the legislative body that voluntarily promulgated the affirmative action law or policy may revoke or terminate its prograin without violating the beneficiaries' procedural due process rights. ${ }^{49}$ Procedural due process rights do not attach to legislative actions; only political protections exist. But where the legislative basis of the beneficiaries' privilege is attacked $\mathrm{n} 1$ a lawsuit, due process requires that the beneficiaries be allowed to intervene to protect the sanie property interests which give thein standing to enjoin violations or nonenforcement of an affirmative action statute, regulation, or policy. ${ }^{50}$

45. So long as the claim is colorable and not patently frivolous, standing under article 111 of the Constitution obtains. Bell v. Hood, 327 U.S. 678 (1946); Hart v. Keith Vandeville Exchange, 262 U.S. 271 (1923). Thus even if such a claim of entitlement does not appear to have inerit, the beneficiaries' standing to assert it is sufficient to mvoke due process.

46. Goldberg v. Kelly, 397 U.S. 254 (1970); Sherbert v. Verner, 374 U.S. 398 (1963).

47. See Rosado v. Wyman, 397 U.S. 397 (1970).

48. Consider the numerous suits in which private parties sued the U.S. Dept. of HEW for nonenforcement of Title VI, 42 U.S.C. $\$ 2000$ (d) (1970), agamst segregated school districts. See, e.g., Adams v. Richardson, 480 F.2d 1159 (D.C. Cir. 1973); Brown v. Weinberger, 417 F. Supp. 1215 (D.D.C. 1976); Adams v. Weinberger, 391 F. Supp. 269 (D.D.C. 1975).

Due process protections attach whether the interests jeopardized are primary or secondary. For instance, under Title VI, patients of a mental hospital have standing to sue for the defendants' discrimmatory hiring practices affecting staff personnel on the basis of the secondary effects on plaintiffs as patients. Marable v. Alabama Mental Health Bd., 297 F.Supp. 291 (C.D. Ala. 1969). See Cypress v. Newport News Gen. \& Nonsectarian Hosp. Ass'n, 375 F.2d 648 (4th Cir. 1967). Similarly students have standing to challenge discriminatory hiring and assigments of teachers. Lee v. Mason County Bd. of Educ., 267 F.Supp. 458 (M.D. Ala.), affd mem. sub nom., Wallace v. United States, 389 U.S. 215 (1967). See Chicano Police Officers Ass'n v. Stover, 526 F.2d 431 (10th Cir. 1975), vacated on other grounds, 426 U.S. 944 (1976); League of United Latin American Citizens v. City of Santa Ana, 12 F.E.P. 651 (C.D. Cal. 1976).

49. For imstance, although welfare recipients may be entitled to a fair hearing prior to termination of mdividual benefits, Goldberg v. Kelly, 397 U.S. 254 (1970), and have standing to seek judicial enforcement of governing statutes and regulations, Rosado v. Wyman, 397 U.S. 397 (1970), they have no legal protection agaimst a state's decision to dismantle its welfare program entirely.

50. Lawsuits challenging public laws mandating that a certain portion of public contracts be awarded to minority contractors and businesses demonstrate that the substantial nature of the 
This point is illustrated by Jospeh Skillker \& Co. v. City of Toledo, ${ }^{51}$ in which minority plaintiffs challenging existing zoning restrictions as unlawfully exclusionary and discriminatory sought rezoning to allow the developinent of low-cost public housing. Neighboring property owners seeking to intervene as party defendants asserted that such rezoning would result in great deterioration and diminution in value of their respective properties. The court noted that these property owners had the right to enjoin violations of existing zoning ordinances. The property interests which gave them that right also gave thein the right to intervene when those interests were being indirectly jeopardized by an attack upon the vahdity of the zoning ordinance. ${ }^{52}$ Although there is hittle doubt that such reliance was based on a "privilege" since the zoning ordinance could have been changed by the local government at any time, the court imphed that "intervention was necessary to accord the property owners due process of law guaranteed by the Fifth Amendment." 53 Hence, the gap between the right to enjoin violations and the right to defend the entitlennent-conferring legislation

beneficiaries' material interest in affirmative action programs also are deserving of legal protection. See, e.g., Public Works Employment Act of 1977, § 103, 42 U.S.C. § 6705(f)(2) (1977) requiring that ten percent of all federal public works contracts designed to stimulate employment go to minority busimess enterprises. Minority contractors, the explicit statutory beneficiaries, lave a legal interest akin to that of a third party beneficiary to a contract, and therefore have standing to enforce the contract. See generally J. Calamari \& J. Perillo, The Law of Contracts 607-13 (2d ed. 1977). See, e.g., Austin v. Sehgman, 18 F. 519 (2d Cir. 1883); Spires v. Hanover Fire lns. Co., 364 Pa. 52, 70 A.2d 828 (1950); Lenz v. Chicago \& N.W. Ry., 111 Wis. 198, 86 N.W. 607 (1901). Specifically, contracts whiclt a government unit enters into in order to secure advantages for the public have been held to create enforceable rights in individual members of the public. lnternational Ry. v. Raun, 224 N.Y. 83, 120 N.E. 153 (1918); Farnsworth v. Boro Oil \& Gas Co., 216 N.Y. 40, 109 N.E. 860 (1915); Pond v. New Rochelle Water Co., 183 N.Y. 330, 76 N.E. 211 (1906). Public contracts specifying minimum wages liave been held enforceable by employees. H.B. Deal \& Co. v. Head, 221 Ark. 47, 251 S.W.2d 1017 (1952); Novosk v. Reznick, 323 lll. App. 544, 56 N.E.2d 318 (1944); Stover v. Wimston Bros. Co., 185 Wasl. 416, 55 P.2d 821 (1937).

In Textile Workers Union of America v. Allendale Co., 226 F.2d 765 (D.C. Cir. 1955), plaintiff, a manufaeturer, sought a review of deternmations by the Secretary of Labor under the Walsh-Healey Act, 41 U.S.C. $\$ 35-45$ (1936), fixing the prevailing minimum wage at a national level for the woolen industry in manufacturing goods under contracts with the government. The circuit court, sitting en banc, allowed the union of employees which would enjoy increased wages under the determination to intervene under the old Fed. R. Civ. P. 24 (1937). While the court in discussing the intervenor union's interest in the litigation never explicitly analyzed the case in terms of third party beneficiary doctrines, it is nevertheless clear that einployees and their unions covered by the Secretary of Labor's determination were intended beneficiaries of the government inanufacturing contracts.

The fact that it may be difficult to identify the particular minority contractors that actually would have been awarded monies pursuant to the "set aside" statute does not vitiate the third party beneficiary analysis. It is established law that a "third party beneficiary contract may exist even if the beneficiary is not named, identifiable, or even in being at the time of contracting. It is sufficient that he be identifiable when the time arrives for the performance of the promise." Calamari \& Perillo, supra at 627. See Restatement of Contracts § 139.

51. 528 F.2d 867 (6th Cir. 1975).

52. Id. at 874 .

53. Id. at 875 . 
was effectively bridged..$^{54}$

The range of interests minority beneficiaries have at stake in reverse discrimination litigation is undeniably expansive. ${ }^{55}$ Beneficiary participation certainly comports with the spirit of due process and with notions of fundanental fairness. This justification for participation is especially compelling in that the beneficiaries' set of interests otherwise would be represented inadequately by the original parties to the litigation.

\section{Interest Representation}

The notion that groups and individuals should have a fair opportunity to participate in decisionmaking processes that directly affect thein represents a familiar denıcratic ideal. That the interest-representation principle has received legal and political cognizance is evidenced by diverse trends and movements ranging from the legislative and judicial vindication of voting rights, ${ }^{56}$ the guarantee of cross-representation of all cognizable groups on juries, ${ }^{57}$ the accordance of system-

54. There are other zoning cases in accord. See Wolpe v. Poretsky, I44 F.2d 505 (D.C. Cir.) cert. denied, 323 U.S. 777 (1944); Rosenberg v. Mehl, 37 Ohio App. 95,174 N.E. 152 (1930); Pritz v. Messer, 112 Ohio St. 628,149 N.E. 30 (1925). In Wolpe, the court observed that "a judgment which declares a zoning order to be void would bind adjoining property owners to the extent of taking away their statutory right to an independent action based on the order." 144 F.2d at 507 . See generally Annot., 35 A.L.R.2d 1135 (1954); Annot., 68 A.L.R.3d 166 (1976).

A similar arguinent was inade by intervening white correctional officers in Kirkland v. New York State Dept. of Correctional Serv., 520 F.2d 420 (2d Cir. 1975), a "forward" discrimination case resulting in the remedial imposition of quotas in promotions. Intervention was sought on the theory that the white officers, otherwise eligible for promotion, were indispensible parties, "since relief sought by plaintiffs would deprivc them of their personal and property rights without due process of law." $I d$. at 423.

This is not to suggest that in every instance where a statute or policy is legally challenged, the dircct beneficiaries thereof have a due process right to participate in the litigation. For instance, where no identifiable class of beneficiaries distinguishable from the general public exists there is no due process claim to be made. But where there is a class of identifiable beneficiaries with a legally enforceable interest, and their interests are not adequately represented by the parties to the lawsuit, due process is implicated. Hansberry v. Lee, 311 U.S. 32 (1940). Indecd, where such a cognizable interest is not adequately defended in a potentially jeopardizing lawsuit, the situation is practically identical to the enforcing agency's failure to enforce an underlying substantive law for which the beneficiaries would liave standing to enjoin.

55. Aside from the variety of material stakes involved, there are, of course, more general legal and political interests. Because the concept of reverse discrimination has not been tested against existing statutory and constitutional law until recently, litigation of such issues will entail unore the effective making of new law than it does the mere application of established principles. The potcntial stare decisis impact of an individual case has legal ramifications not unlike legislation or rule-1naking. Where constitutional issues are litigated the stare decisis impact may be especially significant.

56. See United Jewish Organizations, Inc. v. Carey, 430 U.S. 144 (1977); Harper v. Virgimia Bd. of Elections, 383 U.S. 663 (1966); Reynolds v. Sims, 377 U.S. 533 (1964); Lane v. Wilson, 307 U.S. 268 (1939); Voting Rights Act of 1965, 42 U.S.C. $\S \S 1971-74$ (1965).

57. See Taylor v. Louisiana, 419 U.S. 522, 530 (1974); Williams v. Florida, 399 U.S. 78, 100 (1970); Thiel v. Southern Pacific Co., 328 U.S. 217, 227 (1946); Ballard v. United States, 329 U.S. 
atic community input in localized economic development programs, ${ }^{58}$ and the expansion of standing rights in taxpayers' lawsuits ${ }^{59}$ to the movement toward increased diversification and representation of women and minority groups in private decisionmaking bodies such as corporate boards of directors. ${ }^{60}$ One of the most significant manifestations of the theory and practice of interest representation is the relatively recent broadening of public participation in administrative proceedings. ${ }^{61}$ The legislatures and the courts ${ }^{62}$ have taken significant steps to expand the class of interests entitled to judicial review from agency actions and to permit a variety of interested parties to intervene formally in administrative proceedings.

The interest-representation principle formulated in these fields applies with equal force in reverse discrimination litigation. As a result, beneficiaries of affirmative action programs should have the right to participate in important reverse discrimination litigation. ${ }^{63}$

The fact that the principle of interest representation has been developed primarily in connection with the exercise of legislative power does not prevent it from applying in an adjudicatory context. First,

187, 195 (1946); Glasser v. United States, 315 U.S. 60, 85-86 (1942); Smith v. Texas, 311 U.S. 128; 130 (1940); Mitchell v. Johnson, 250 F. Supp. 117, 121 (M.D. Ala. 1966).

58. See, e.g., Cal. Health \& Safety Code $§ 33385$ (West Supp. 1978).

59. Flast v. Cohen, 392 U.S. 83 (1968). But see Simon v. Eastern Ky. Welfare Rights Organization, 426 U.S. 26 (1976).

60. Medical Comm. for Human Rights v. SEC, 432 F.2d 659 (D.C. Cir. 1970), vacated as moot, 404 U.S. 403 (1972); P. Blumberg, CoRporate Responsibility in a Changing SoCieTY (1972); Chayes, The Modern Corporation and the Rule of Law, in THE CORPORATION IN MODERN SOCIETY (E. Mason ed. 1959); Schwartz, The Public Interest Proxy Contest: Reflections on Campaign GM, 69 MrCH. L. REv. 421 (1971).

61. Federal Admimistrative Procedure Act, 5 U.S.C. $\$ \$ 553-54$ (1977).

62. See FCC v. Sanders Brothers Radio Station, 309 U.S. 470 (1940) (broadcaster, financially imjured by the FCC's issuance of a hicense to a competitor, had standing under Section 402(b) of the Communications Act, 47 U.S.C. $§ 402$ (1962), to seek judicial review of that action); Office of Communication of the United Church of Christ v. FCC, 359 F.2d 994 (D.C. Cir. 1966) ("responsible" listener representatives allowed to intervene in the licensing proceedings of a radio station in order to vindicate the public interest even though the FCC was already cliarged with the mandate of protecting the public interest). See generally K. Davis, ADMINISTRATIVE LAW, \$ 8.11 (1972); L. Jaffe, Judicial Control of Administrative Action (1965); Cramton, The Why, Where, and How of Broadened Public Participation in the Administrative Process, 60 GEo. L. J. 525 (1972); McLachlan, Democratizing the Administrative Process: Toward Increased Responsiveness, 13 ARIz. L. Rev. 835 (1971); Shapiro, supra note 26; Stewart, Reformation of American Administrative Law, 88 HaRv. L. Rev. 1667, 1748-60 (1975).

63. The value and effectiveness of interest representation theory is not without criticism. Probably most notable is Professor Stewart's discussion in The Reformation of American Administrative Law, 88 HARv. L. Rev. 1667, 1723-47 (1975). But Professor Chayes points out that as to those misgivings whicl do not pertain primarily to the administrative law context, there are a vast array of judicial procedures that can be utilized to enable the courts to select among and facilitate effective participation of pertiment interests. Chayes, The Role of the Judge in Public Law Litigation, 89 HARv. L. REv. 1281, 1310-13 (1976). More particularly, where a single definitive set of interests are intimately affected, as are the beneficiaries in reverse discrimination lawsuits, Professor Stewart's misgivings are not pertinent. 
judicial procedures such as joinder, intervention, and class representation have been developed to facihtate the representation of effected absentee interests in inultiparty hitigation. ${ }^{64}$ More importantly, the hitigation of constitutional or statutory policies closely resembles legislative acts. Professor Chayes points out that in contrast to the traditional model of adjudication, ${ }^{65}$ which arises out of an ad hoc dispute between private parties about private rights, public law litigation (such as school desegregation and prison reform cases) is distimguishable im the following respects:

(a) The party structure is not bipolar, but sprawling and amorphous;

(b) The fact inquiry is not only historical and adjudicative, but predictive and legislative;

(c) The subject inatter is not a dispute between private individuals about private rights, but a grievance about the operation of public policy;

(d) The ordered relief does not look inerely to past wrongs and is not confined to the immediate parties; rather it is usually forward looking, reinedially fashioned, often having important consequences for inany persons including absentees. ${ }^{66}$

Reverse discrimination litigation predicated upon statutory or constitutional causes of action is a clear example of public law hitigation. ${ }^{67}$

Moreover, the fact that the issues of "reverse discrimination" are being judicially resolved has special significance. Given the historically defined and pohtically assigned antimajoritarian role of the courts, ${ }^{68}$ minority groups are more likely to protect their interests successfully and obtain redress through the judiciary than through the legislature. Given the safeguards estabhished to protect the rights of minorities to participate in the legislative and executive branches of government, ${ }^{69}$

64. See Chayes, supra note 63, at 1289-92.

65. See generally L. Fuller, The Morality of LAW (1969).

66. See Chayes, supra note 63 , at 1302 .

67. There are more than two sets of interests that require representation; contrary to Justice Stevens' characterization of Bakke that the case was only a private dispute, the controversy is a public one affecting innumerable programs and individuals; and the fact inquiry is colorcd by public pohicy considerations and normative judgments. Take, for instance, the subtle and complex factual issues upon which the Bakke decision is predicated, e.g., whether minorities are stigmatized by special admissions programs and whether any such stigma outweighs that attached to their de facto exclusion from professional schools entirely, whether minority professionals are more effective practitioners in mimority areas than whites, to what degree societal discrimmation is responsible for mimority underrepresentation in professional schools, what degree of white resentment is raised by race-based preferential treatment accorded to minorities, whether racial perceptions and harmony are best served by absolute color-blind policy or temporary race-conscious remedial efforts, and whether there are other administrable alternative methods of admitting meanimgful numbers of minorities.

68. United States v. Carolene Prods. Co., 304 U.S. 144 (1938). See generally Choper, On the Warren Court and Judicial Review, 17 CATH. U. L. REv. 20 (1967); Cox, The Role of the Supreme Court in American Society, 50 MARQ. L. REv. 575 (1967); Wright, Professor Bickel, The Scholarly Tradition, and the Supreme Court, 84 HaRv. L. REv. 769 (1971).

69. See notes 56-63 and accompanying text supra. 
minority participation in the adjudicatory process also must be secured where their substantial and concrete interests are immediately threatened.

Finally, it must be recognized that minorities historically have been excluded froin the inainstreain of American society. Affirmative action prograins to a significant extent owe their existence to the civil rights movement and urban unrest of the 1960's, and that period of social turmoil often has been attributed in part to the effective exclusion of minorities from the political decisionmaking process. ${ }^{70}$ This exclusion can be renedied only if minorities are accorded full participation in the nation's decisionmaking processes, including judicial determinations that vitally affect thein. A denial of a full advocatory role to representatives of ininority beneficiaries in reverse discrimination suits that inay shape the long-term social conditions in minority communities would constitute a cruel irony: minorities would be denied ineaningful participation in the very dispute-resolution process that will determine whether other important means of assuring thein full political participation in the future ${ }^{71}$ will be vindicated. ${ }^{72}$

\section{II}

\section{Procedural Devices for Beneficiary Participation}

Theory dictates that minority beneficiaries of affirmative action programs be allowed to participate in reverse discrimination suits. This can be accomplislied througl existing provisions of the Federal Rules of Civil Procedure. Compulsory joinder under rule 19(a) should be considered as the most effective device, although few courts may be willing to expand the scope of that rule to cover reverse discrimination litigation. Therefore, the means that lends itself inost readily to accoinmodating the need for minority participation is the right of intervention under rule 24(a).

\section{A. Intervention as of Right Under Rule 24(a)}

Rule 24(a) provides:

(a) Intervention of Right. Upon timely application anyone shall be permitted to intervene in an action:

70. See Report of the National Advisory Commission on Civil Disorders (1968).

71. For example, an important articulated goal of remedial race-conscious programs in education, notably of law schools, is the facilitation of access of mimorities to important social and political institutions im order to imcrease their participation in the resolution and formulation of social, legal, and political policies.

72. While this irony points out a potential nexus between the merits of the substantive legal issues and the policy argumg for mmority beneficiary participation in lawsuits as a procedural matter, the issue of the right of participation need not depend upon the validation of "preferential treatment" since the notion of interest representation as a general matter is a race-neutral concept. 
(2) when the applicant claims an interest relating to the property or transaction which is the subject of the action and he is so situated that the disposition of the action may as a practical matter impair or impede his ability to protect that interest, unless the applicant's interest is adequately represented by existing parties. ${ }^{73}$

Minority beneficiaries of affirmative action programs who seek to intervene im reverse discrimination lawsuits meet all three requirements of rule 24(a)(2). Beneficiaries have the requisite interest in the litigation, their ability to protect that interest is potentially impaired, and they are inadequately represented by the original parties.

\section{Interest in the Litigation}

Although rule 24 was amended in 1966 to liberahize some of the threshold requisites for intervention, ${ }^{74}$ it has been asserted that:

there is nothing in the new rule or in its attendant commentary to indicate that it effected a change im the kind of interest required. Thus the thrust of the revision seems clearly to be concerned with the adequacy of representation and not with any notion of expanding the types of interest that will satisfy the rule. Still required for intervention is a direct, substantial legally protectable interest in the proceedings. ${ }^{75}$

Assuming the correctness of this conservative view, the substantial interests of minority beneficiaries in reverse discrimination suits are sufficient. The "legally protectable interest" is closely analogous to the "personal stake in the outcoine of the controversy" that is required for standing to sue under article III of the Constitution. ${ }^{76}$ Indeed, commentators have specifically pointed to the conceptual nexus between standing to intervene and standing to initiate litigation in the first place. ${ }^{77}$ As discussed earlier, ${ }^{78}$ the beneficiaries' interests in the material benefits created by the affirmative action prograin (admissions, employinent opportunities, public contracts, increased medical services, integrated pohice forces, etc.) warrants standing to protect and enforce those interests. Where there is a colorable claim that the affirmative action program is legally coinpelled as a consequence of the defendant's past or present unlawful discriminatory conduct towards minori-

73. FED. R. Civ. P. 24(a)(1) provides for intervention "when a statute of the United States confers an unconditional right to intervene."

74. See Advisory Committee's Note to the 1966 Amendinent of Rule 24.

75. Hobson v. Hansen, 44 F.R.D. 18, 24 (D.D.C. 1968), aff'd sub nom. Smuck v. Hobson, 408 F.2d 175 (D.C. Cir. 1969) (einphasis added).

76. Baker v. Carr, 369 U.S. 186, 204 (1962). Indeed, standing to sue formerly was couched in terms of the requirement of a "legally protectable interest." See Jenkins v. McKeithen, 395 U.S. 411 (1969).

77. See Chayes, supra note 63, at 1290-92; Kennedy, Let's All Join In, 57 KY. L.J. 329, 346 n.43 (1969); Stewart, supra note 62, at 1748-60.

78. See notes $46-55$ and accompanying text supra. 
ties, the beneficiaries' standing to sue to enjoin the defendant from elimmating the reinedial affirmative action program is even more clear. $^{79}$

Although the standing test provides a convenient means of analyzing the interest requirement of rule 24(a)(2), it must be kept in mimd that standing to intervene is generally broader than standing to sue. ${ }^{80}$ Thus, because minority beneficiaries have sufficient interests at stake to sue on their own behalf to redress discriminatory practices or to preserve remedial programs, they also have sufficient interests to allow intervention as of right under even the conservative treatment of rule 24(a) as amended.

Most authorities argue that the effect of the amendment was to hiberalize the intervenor's requisite stake in the litigation, and it is now established that the intervenor's interest need not amount to a specific legal or equitable interest in the chose. ${ }^{81}$ Thus, while the denial of intervention under old rule 24(a) is not dispositive in the application of the interest test under the new rule 24(a), the "fact that intervention was allowed under the old rule indicates intervention is proper a fortiori under the less restrictive standard of the new rule." 82 Courts have held that interests as broad and anorphous as "the [state's] public im-

79. The fact that such a claim might appear unlikely to prevail on the merits does not vitiate the beneficiaries' standing to sue; so long as the claim is colorable and not patently frivolous, standing under article III of the Constitution obtains. See note 45 supra. And the fact that the defendant institution found it necessary to institute a race-remedial program imphes that minorities were disproportionately excluded in the past or in the regular admission process and raises by definition at least a colorable claim of past discrimination.

80. United States v. Board of School Comm'rs, 466 F.2d 573, 577 (7th Cir. 1972), cert. denied, 410 US. 909 (1973). See Shapiro, supra note 20, at 726.

The article III himitation on standing to sue is based on a set of constitutional and prudential considerations entirely different from the pohicies that allow an outside party to participate in an existing suit. Article III standing and justiciability concerns the jurisdiction and power of the judiciary to hear a particular case, Massachusetts v. Mellon, 262 U.S. 447 (1923), assurance of the integrity of the judicial process, Muskrat v. United States, 219 U.S. 346 (1911), and more recently manageinent of the judicial docket, Warth v. Seldin, 422 U.S. 490 (1975). In the context of an apphication for imtervention in an existing suit, the threshold determination as to the jurisdictional power of the court to hear the case presumably has already been resolved. In terms of the assurance of a live controversy and vigorous adversity (see notes 20-35 and accompanying text supra), one of the principal reasons for permitting minority intervention in reverse discrimination suits is precisely to assure vigorous adversity and the full disclosure of all the pertiment facts.

81. United States v. American Inst. of Real Estate Appraisers, 442 F. Supp. 1072, I080 (N.D. Ill. 1977). See Smuck v. Hobson, 408 F.2d 175, $179-80$ (D.C. Cir. 1969) (In reversing the narrow "interest" test in Hobson v. Hansen, 44 F.R.D. 18 (D.D.C. 1968), the court stated that the requirement of an "interest" in the suit "should be viewed as a prerequisite rather than relied upon as a determinative criteria for intervention. If barriers are needed to limit extension of the right to intervene, the criteria of practical harm to the applicant and the adequacy of representation by others are better suited to the task."); Nuesse v. Cainp., 385 F.2d 694, 700 (D.C. Cir. 1967) (The interest test was recast as "primarily a practical guide to disposing of lawsuits by imvolving as many apparently concerned persons as is compatible with efficiency and due process.").

82. C. Wright \& A. Miller, Federal Practice and Procedure $\S$ I907, at 483, $485-87$ (1972). See also Shapiro, supra note 20, at 729-40. 
terest in a competitive [natural gas] system," 83 " "the competitive equality' of national and state banks in general," 84 the preservation of "the general health of the population as a fundamental element of the public interest,"85 and the educational environment of one's children ${ }^{86}$ were a sufficient basis for intervention under the new rule. The interests of minority beneficiaries are as immediate, and hence are clearly sufficient for purposes of rule 24(a) intervention.

\section{Inability to Protect an Interest}

Rule 24(a) also requires that a potential intervenor be able to deinonstrate that his or her interest may be adversely affected by the hitigation. ${ }^{87}$ The classic instance of an absentee being adversely affected by hitigation occurs where there are competing claimants to a limited fund. The common fund situation is covered by new rule $24(a)^{88}$ since the absentee claimant will be "adversely affected as a practical matter" [emphasis added]; while he or she would not be legally bound by the action disposing of all or a substantial portion of the cominon fund, this would be little comfort if the fund is exhausted or depleted. 89 "Reverse discrimination" suits are in many ways similar to

83. Cascade Natural Gas Corp. v. El Paso Natural Gas Co., 386 U.S. 129, 135 (1967).

84. Nuessa v. Camp., 385 F.2d 694, 701 (D.C. Cir. 1967).

85. Bass v. Richardson, 338 F. Supp. 478, 492 (S.D.N.Y. 1971) (Memorandum on Motion to Intervene).

86. Smuck v. Hobson, 408 F.2d 175 (D.C. Cir. 1969); Johnson v. San Francisco Unified School Dist., 500 F.2d 349 (9th Cir. 1974).

87. Prior to the 1966 amendment, the old rule 24(a) required that the intervenor be either "bound by a judgment in the action" or "adversely affected by a distribution or other disposition of property which is in the custody or subject to the control or disposition of the court." Being "bound by the judgment" was interpreted in Sam Fox Publishing Co. v. United States, 366 U.S. 683 (1961), as requiring that the intervenor applicant be bound under res judicata principles. This narrow construction resulted in a logical dilemina for the prospective intervenor since, if he were madequately represented in the underlying action, he would not be bound to that action under res judicata. The alternative test of being affected by disposition of property in the court's custody was primarily apphied to in rem actions involving competing claimants to a common fund or property. See Hunt Tool Co. v. Moore, lnc., 212 F.2d 685 (5th Cir. 1954); Unitcd States v. American Soc. of Composers, Authors, \& Publishers, 202 F. Supp. 340 (S.D.N.Y. 1962). The 1966 amendinent was intended to do away with the narrow conception of both a requisite in rem fund and the Sam Fox Publishing Co. interpretation of "bound," and to focus attention upon the potential practical effect of the underlying action on the intervenor apphicant.

88. The common fund situation was exphicitly covered under the old rule 24(a)(3).

89. The limited fund analysis has also been apphed in the context of adjudicatory decisions made by administrative agencies. Many statutes governing adınimistrative agencies accord intervention rights in administrative proceedings to persons "adversely affected or aggrieved" by an agency action. See, e.g., Section 10(a) of the Federal Admistrative Procedure Act, 5 U.S.C. $\S 702$ (1970). The courts have consistently permitted intervention by competing claimants in agency actions involving the allocation of scarce resources such as the granting of a limited number of hicenses to a greater number of applicants. FCC v. National Broadcasting Co., Inc. (KOA), 319 U.S. 239 (1943); Metropohtan Television Co. v. United States, 221 F.2d 879 (D.C. Cir. 1955); American Broadcasting Co. v. FCC, 191 F.2d 492 (D.C. Cir. 1951). Similarly in actions involving the awarding of governınental contracts, competing bidders challenging awards to 
cases where multiple claimants compete for a limited fund. The "fund" is the finite amount of available admissions slots, financial aid, employment or promotional opportunities, or public contracts. ${ }^{90}$ With respect to this fund, the legal claims of the reverse discrimination plaimtiff and minority beneficiaries are mutually exclusive.

Beyond the extreme example of competing claimants to a common fund, the caselaw indicates that the courts are quite willing to find the potential harm that warrants intervention. In Ford Motor Co. v. Bisanz Brothers, Inc., ${ }^{91}$ Ford Motor Company sought intervention in a suit brought against a railroad coinpany by adjoining property owners seeking to enjom a nuisance. The court allowed Ford to intervene because an mjunction curtailing the railroad's operations would force a curtailment of Ford's manufacturing activities. Similar reasoning was used by the Supreme Court in Cascade Natural Gas v. El Paso Natural Gas $^{92}$ decided immediately after rule 24 was amended in 1966 . In that case, the underlying antitrust action prosecuted by the government culminated in a consent decree; the decree was opposed by the State of California, representing the primary consumers of the defendant. The effect of the settlement allegedly threatened the "competitive factor" in natural gas available to Califormans; this adverse effect was found sufficient to warrant imtervention. ${ }^{93}$ The invalidation of an affirmative action program will cause similar adverse effects; for instance, the number of doctors serving ininority cominunities or the economic growtll of minority busimesses inay decline.

The impairment of the material imterest need not be caused by direct legal operation of the underlying action. The extreme requirement that the absentee be bound by res judicata has been abandoned by the

competitors as being contrary to statutes or regulations have been accorded intervention rights. William F. Wilke, Inc. v. Department of the Army, 485 F.2d 180 (4th Cir. 1973); Blackhawk Heating \& Plumbing Co. v. Driver, 433 F.2d 1137 (D.C. Cir. 1970); Scanwell Labs, Inc. v. Shaffer, 424 F.2d 859 (D.C. Cir. 1970). See Stewart, Reformation of American Administrative Law, 88 HARV. L. REV. 1667, 1734 n.314 (1975).

90. It can be argued that with respect to reverse discrimination cases, the potential number of slots or opportunities is not fixed. For example, a umiversity might expand the total number of admissions openings in order to accommodate larger numbers of candidates. Still, the number of available positions at any particular point in time is finite and there is no assurance that competition and the mutually exclusive claims of white plaintiffs and minority beneficiaries can ever be eliminated by the establishment of an "open enrollment" policy. Even were the resources available, it is extremely unlikely that a court would attempt to compel a school to substantially expand its enrollment, much less force an employer to expand its workforce.

91. 249 F.2d 22 (8th Cir. 1957). The case, decided under the old rule 24 (a)(2), portended the approach under the new rule as amended in 1966.

92. 386 U.S. 129 (1967).

93. Although the case has been criticized for its extremely broad holding, the criticism has been primarily directed at the apphication of the interest and inadequate representation tests. See Kaplan, Continuing Work of the Civil Committee: 1966 Amendments of the Federal Rules of Civil Procedure, 81 HARv. L. Rev. 356, 403-07 (1967); Note, 81 HARv. L. Rev. 221-25 (1967). 
new rule; ${ }^{94}$ mdeed some courts have gone as far as holding that the effects of mere stare decisis may be sufficient to justify intervention. In Atlantis Development Corp. $v$. United States, ${ }^{95}$ at dispute were the use of and the ownership rights im a number of coral reefs and islands. The United States brought suit to enjoin the defendants from building structures on the islands, claiming that the islands were part of the Outer Continental Shelf, and hence subject to the jurisdiction, power, and control of the government. A developinent company which had previously given notice to the government of its claim to ownership sought to interpose its defense agamst the plaintiff government and to cross-claim against the defendants. The court held that the development company was entitled to intervene as of right under rule 24(a)(2). Significantly, the potential stare decisis effect upon the intervenor in event the government were to prevail in the main action was held suffcient to constitute "impairment" of an intervenor's interest for the purposes of rule 24. ${ }^{96}$ When the Atlantis Development test is apphed to reverse discrimination suits, a sufficient impairment of the minority beneficiaries' ability to protect their interests is evident, especially given the particular importance of stare decisis in the developing area of "reverse discrimination" law.

More significantly, Atlantis Development went beyond its stare decisis holding to give flesh to the rule's focus on the practical effect upon the intervenor's interest. Noting the Fifth Circuit's tradition of upholding panel decisions, the court stated, "the only way by which [intervenor] Atlantis.can win is to secure a rehearing en banc with a successful overruling of the prior decision or, failing in either one or both of those efforts, a reversal of the earlier decision by the Supreme Court on certiorari," 97 a slim possibility given the sniall number of en banc hearings and sinall percentage of cases meriting certiorari from the Supreme Court.

The court applied a similar analysis in Smuck v. Hobson.$^{98}$ White parents of school children in the Washington D. C. Public School District were allowed to intervene in order to appeal court-ordered school

94. See note 87 supra.

95. 379 F.2d 818 (5th Cir. 1967).

96. But the court additionally relied upon the fact that the intervenor's inaterial interest in the case was the very same property at stake in the underlying case (i.e., the specific group of reefs). Id. at 829 . The court thereby set a doctrinal limitation necessary to prevent the boundless application of its broad analysis. See also Nuesse v. Cainp, 385 F.2d 694, 702 (D.C. Cir. 1967) (holding in accord with Atlantis Development that "stare decisis principles inay in some cases supply the practical disadvantage that warrants intervention as of right.") That requirement would, of course, be met in the reverse discrimination lawsuit where the plaintiffs and beneficiarics are competing for the same material stake.

97. 379 F.2d at 828.

98. 408 F.2d 175 (D.C. Cir. 1969). 
integration, ${ }^{99}$ even though the defendant Board of Education decided not to appeal the trial court order. The court reasoned that if intervention were to be denied and the decree finalized, the parents' only recourse would be to assert in a subsequent lawsuit that the Board's compliance with the trial-court order would be unconstitutional. Because this would be a "sterner challenge"100 than that the parents would be required to undertake as intervenors - in which case they would only have to sliow that the integration plan was not constitutionally required-their imterests would be affected "as a practical matter." Hence the court allowed intervention.

The analysis used in Smuck applies equally well in reverse discrimination suits. If intervention is demed in the action in which plaintiff succeeded in estabhshing reverse discrimination, minority groups would be forced to pursue their imterests in a subsequent action by asserting that the program was constitutionally or statutorily coinpelled as a result of past discrimination or biased selection procedures. ${ }^{101}$ This would amount to a "sterner challenge" similar to that faced by the intervening parents in Smuck. ${ }^{102}$

99. Hobson v. Hansen, 269 F. Supp. 401 (D.D.C. 1967).

100. 408 F.2d at 181 .

101. For a discussion of the difficulty of proving that an affirmative action program is constitutionally rcquired when the potential defendant has instituted an affirmative action program without being judicially, administratively, or legislatively compelled, see note 29 supra.

102. The "sterner challeuge" is premised upon the assumption that proving a policy to be legally compelled is more difficult than demonstrating it to be merely permissible. That general proposition applies to affirmative action programs under Bakke simce some programs, such as the Harvard admissions policy lauded by Justice Powell, may be permissible yet not compelled by law. Such programs need not be validated by a finding of specific past institutional discrimination under Bakke where they can be sustaimed by compelling state interests independent of the defendant's past conduct such as the first amendment interest in educational diversity. However, as to the more extreine programs utilizing racial quotas, Justice Powell's opinion appears to require a finding of an identifiable constitutional or statutory violation in order to validate the type of program established by Davis medical school. Under this constitutional analysis, the showing that minority intervenors must make in the reverse discrimination suit may be theoretically jnst as cxacting as that necessary in a subsequent forward discrimination lawsuit. But to hitigate a second suit successfully may still be more difficult as a practical matter than intervening and successfully defending the affirmative action program in the first suit. First, the burden of proof on the past discrimination issue arguably lies with the reverse discrimination plaintiff, whereas minority beneficiaries would carry the burden in the subsequent forward discrimination suit. Even assuming that the beneficiaries would have the burden in either instance, intervention in the initial lawsuit places then in a better posture given the imertia and stare decisis force of the first judgment and the fact that the second suit might be perceived by the court as an inipermissible collateral attack upon the first judgment. See note 143 infra.

More importantly, since all of the justices did not address the coustitutional question in Bakke, Justice Powell's view as to the requisite showing of past discrimination nccessary to validate race-remedial quotas probably represents only the tentative position of the Court. It is certainly conceivable that the Court will ultimately settle upon an imtermediate position, requiring something more than a showing of general societal discrimination, but less exacting than a demonstration of a prior substantive constitutional or statutory violation. See Lau v. Nichols, 414 U.S. 563 (1974). Compare the Fifth Circuit's decision in Weber v. Kaiser Aluminum \& Chem. Corp., 563 F.2d 216 (5th Cir. 1977), cert. granted, 47 U.S.L.W. 3408 (Dec. 11, 1978), based on Title 
A decision adverse to affirmative action programs based upon constitutional grounds would effectively put any remedy available to minorities beyond the reach of legislative and executive action. ${ }^{103}$ Indeed, where a case, such as Bakke, reaches the United States Supreme Court, the only recourse might be amendment of the Constitution. Even if the reverse discrimination case is decided upon statutory grounds, the ability of minority groups to protect their interests in the affirmative action program will be significantly impaired. While legislative vindication of minority groups' rights and imterests is theoretically available, politically disadvantaged racial minorities are less likely to obtain satisfaction in the legislature than in the courts. ${ }^{104}$ The difficulty is especially formidable because ininority groups are likely to have concentrated pohitical clout within a limited region or upon a particular local institution, but the remedy unust be effected by the federal or state legislatures. And current public antagonism towards race-based preferential programs may render the task virtually impossible. Thus the practical impairment analysis of rule 24(a) as applied in Smuck and Atlantis is met in reverse discrimination lawsuits.

\section{Inadequate Representation of Intervenor's Interest by the Original Parties}

Rule 24(a) also requires that the intervenor's interest be inadequately represented by the existing parties. Under the old Rule, there was authority that proof of either a conflict of interest between the intervenor and the party supposed to represent his interest, ${ }^{105}$ a complete failure of representation by existing parties, ${ }^{106}$ or collusion or likelihood of collusion betwcen them, ${ }^{107}$ was necessary to ineet the inade-

VII. The panel majority effectively held that an affirmative action program is either legally compelled (i.e., justified by a past Title VII violation) or invalid. Judge Wisdom's dissent pointing out this paradoxical "tightrope" admits this. Id. at 230. In contrast, his proposal of allowing the employer a "zone of reasonableness" within which the affirmative action prograin could be voluntarily estabhished without reverse discrimination hability, would place a substantial wedge between permissible and compelled programs. $I d$.

103. Whether such is the case, however, will depend upon the specific analysis relied upon by the courts. For mstance, it may be that certain voluntary affirmative action prograns by state and local universities are forbidden absent a specific congressional mandate; but that under the enforcement provision of the fourteenth amendment as interpreted by Justice Brennan in Katzenbach v. Morgan, 384 U.S. 641 (1966), Congress may lawfully enact legislation specifically requiring universities whose regular admissions policies have a racially disparate impact to institute race-conscious renuedial programs. See $98 \mathrm{~S}$. Ct. at $2755 \mathrm{n} .4 \mathrm{I}, 2787-88 \mathrm{n} .42$. Hence, the legislature nuay in theory have the last word. The actual possibility, however, of obtaining such legislation through the political process would still be a formidable task for minority groups.

104. See generally 98 S. Ct. 2733, 2782-85 (I978); United States v. Carolene Prod. Co., 304 U.S. 144 (1938).

105. Pyle-National Co. v. Amos, 172 F.2d 425 (7th Cir. 1949).

106. Pellegrimo v. Nesbit, 203 F.2d 463 (9th Cir. 1953).

107. Cuthill v. Ortman-Miller Machine Co., 216 F.2d 336 (7th Cir. 1954). 
quate representation requirement. ${ }^{108}$ While some authorities contend that the same standard was carried over into the new rule, ${ }^{109}$ the better view is that the change in wording established by the 1966 Amendment- "unless the applicant's interest is adequately represented"-was ineant to liberalize the previous rigid standard. ${ }^{110}$ Indeed, some courts have held that this change of wording shifts the burden of proof on this issue to the party opposing intervention ${ }^{111}$ and that only a minimal showing on the intervenor's part need be made. ${ }^{112}$

The most extreine example of lack of adequate representation of the intervenor's imterest in the hitigation is the collusive suit between plaintiff and defendant. ${ }^{113}$ The problem of collusion between opposing parties goes to the heart of the "case or controversy" clause of article III of the United States Constitution. ${ }^{114}$ This constitutional dimension to the problem of collusive or minimally adverse suits compels the resolution of reasonable doubt as to the possibility of collusion in favor of establishing inadequacy of representation under rule 24(a) in the reverse discrimination context. ${ }^{15}$ This is especially justified because reverse discrimination suits are particularly susceptible to the problem of the minimally adverse defendant that has been legally or politically pressured into instituting an undesired affirmative action policy in the

108. See generally 3 Moore's Federal Practice $\$ 24.07$ (2d ed. 1978); C. Wright \& A. MilleR, supra note 82, at 521; Annot., 84 A.L.R.2d 1412, 1419-22 (1962).

109. Cascade Natural Gas v. El Paso Natural Gas, 386 U.S. 129, 155-56 (1967) (Stewart, J., dissenting); Kennedy, supra note 77, at 353-54.

110. C. WRIGHT \& A. Miller, supra note 82, at 521-22. Previously, rule 24(a)(2) provided for intervention "when the representation of the apphicant's interest by existing parties is or may be inadequate."

111. Smuck v. Hobsen, 408 F.2d 175, 181 (D.C. Cir. 1969); Nuesse v. Camp, 385 F.2d 694, 702 (D.C. Cir. 1967); Exchange Nat'l Bank of Chicago v. Abramson, 45 F.R.D. 97, 103 (D. Minn. 1968).

112. Trbovich v. United Mineworkers of America, 404 U.S. 528, 538-39 n.10 (1972); Kozak v. Wells, 278 F.2d 104, 110 (8th Cir. 1960); Shultz v. Umited Steelworkers of America, 312 F. Supp. 538, 539 (W.D. Penn. 1970).

113. See text accompanying notes 21-28 supra.

114. The "honest and antagonistic assertion of rights" is a necessary element of the justiciability of a lawsuit, since it is "a safeguard essential to the integrity of the judicial process, and one which we have held to be indispensible to adjudication of constitutional questions." United States v. Johnson, 319 U.S. 302, 305 (1943). Ironically, Professor Wright points out that two landinark constitutional decisions, Fletcher v. Peek, 10 U.S. (6 Cranch) 87 (1810), and Dred Scott v. Sandford, 60 U.S. (19 How.) 393 (1856)-litigation involving important rights of minority groups and decided adversely to their imterests-"have come in what now seems to have been collusive cases." C. WRIGHT, HANDBOOK of THE LAW OF FEDERAL CourTs 40 (3rd ed. 1976). See Schear, Ancestors of Bakke-The Denial of Minority Rights Through Court Cases Between Whites-A Long Tradition, in AfFirmative Action In CRISIS: A HandBook for ACtivists (National Lawyer's Guild and the National Conference of Black Lawyers eds. 1977).

115. While the application of the "case or controversy" doctrine of article III in testing the plaintiff's standing is the primary safeguard against collusive or mimimally adversative lawsuits, no such protections obtain where lack of adversity stems froun the nature of the defendant's rather than plaintiffs interest in the litigation. In this situation, the cure lies in enlarging the suit to encoinpass a multiplicity of parties to enhance full adversity. 
first place. ${ }^{116}$

Short of actual or suspected collusion, resulting in the coinplete failure of defense, differences between the intensity of the interests of the defendant and beneficiaries can significantly affect the course of hitigation. ${ }^{117}$ For instance, the decision of whether to settle with the opposing party or appeal an adverse decision will turn upon the overall intensity of the defendant's interest at stake. In Smuck v. Hobson, ${ }^{18}$ it is evident that a difference in interests between the defendant school board and intervening white parents resulted in different responses to the trial court's integration order. Similarly, in the landmark case of Evans $v$. Newton, ${ }^{119}$ a city administering a trust with a racially restrictive covenant was sued by white residents for failing to enforce that covenant. The city capitulated and tendered resignation as trustee, and the state court appointed three individuals as new trustees. There is no suggestion that the suit was collusive. More likely, the city was not sufficiently interested in administering the trust to defend its position. Had it not been for the intervention of several black citizens, the appeal up to the Supreme Court of Georgia and then to the United States Supreune Court would not have been made.

Although some cases have stated that mere differences in trial strategies and tactics alone will not render representation of the imter-

116. And the potential for collusion or lack of adverseness is further exacerbated in the context of professional school admissions where it is common for candidates to apply to numerous schools. The trial record in Bakke established that in 1973, Alan Bakke applied to 13 medical scliools and was rejected by all of thcin. The rejected white applicant, wishing to contest the legality of minority admissions programs generally is likely to liave a number of schools from which to choose in naming a dcfendant. Agam, the record slows that Bakke conteinplated suing a number of other scliools including Stanford and the University of California at San Francisco before suing the Davis medical school. All other things being equal, it is to the plaintiffs advantage to choose the school with a weak ideological commitment to its minority prograin or limited litigation resources.

117. See generally notes 21-23 supra. Even where affirmative action has not been exogenously coerced, it is not unlikely that the policymaking body of the defendant institution is itself deeply divided over the highly clrarged issue of race-preferential prograns. The existence of a dissenting viewpoint within any decisionmaking body could result in compromise pertaming to litigation tactics and strategies, and the amount of institutional resources and effort afforded to the defense of the program.

Bakke is an illustration of the instrumental role a dissenting factor could play in the conduct of the litigation. After losing in the California Supreme Court many mimority groups urged the University not to appeal the case to the United States Supreme Court for fear of problems stemming from the bad trial record and of an expected adverse decision coming from the conservative Burger Court. Daily Californian Jan. 17, 1977, at 10. The Regents eventually eschewed this concern and decided to petition for certiorari. While those voting to take the appeal inust have included those who were committed to the special admission program and who held a more optimistic view of the prospects for reversal, it is certainly conceivable that some who were hostile to the program voted to take the appeal looping for an affirmance of the California Supreme Court's decision that would have national effect.

118. 408 F.2d 175 (D.C. Cir. 1969).

119. 382 U.S. 296 (1966). 
venor's interest inadequate, ${ }^{120}$ differences in the intensity and character of the interests between the original parties and intervenor have warranted the granting of intervention even where it is not clear exactly how their conduct of the litigation might differ ${ }^{121}$ In Ford Motor Co. $v$. Bisanz Brothers, Inc. ${ }^{122}$ despite no evidence of conflicting interests between the defendant railroad companies and Ford, the latter was granted intervention as of right. The court found that the interests of Ford and the railroad coinpanies were distinguishable, although it was clear that both defendants and intervenor sought to keep the railway lines open. Underlying the court's decision was the feeling that the railroad operation had greater economic value to the intervenor than to the defendant. ${ }^{123}$ In Holmes $v$. Government of Virgin Islands, ${ }^{124}$ the vahidity of a statute authorizing a particular developinent project was challenged. Although both the defendant government and a private corporation sought a determination uplolding the statute, the court granted intervention because the corporation had a large, immediate financial interest in the project which appeared more intense than the defendant's interest.

Even absent exphicit collusion, where the establishment of the challenged affirmative action prograin was not entirely voluntary, as in Weber and $E E O C$ v. $A T \& T,{ }^{125}$ the possible difference in interest intensities may well border on collusion. Beneficiary intervention under these circumstances is undoubtedly warranted, especially in view of the extraordinary legal and inaterial stakes involved. 126

120. See C. Wright \& A. Miller, supra note 82, § 1909, at 531.

121. See Nuesse v. Camp, 385 F.2d 694, 703 (D.C. Cir. 1967); Atlantic Refining Co. v. Standard Oil Co., 304 F.2d 387, 393 (D.C. Cir. 1962); Textile Workers Union of America v. Allendale Co., 226 F.2d 765, 768 (D.C. Cir. 1955), cert. denied, 351 U.S. 909 (1956); Bass v. Richardson, 338 F. Supp. 478, 491-92 (S.D.N.Y. 1971); United States v. Reserve Mining Co., 56 F.R.D. 408, 414-15 (D. Minn. 1972); In re Oceana Int'1, Inc., 49 F.R.D. 329, 332-33 (S.D.N.Y. 1970). But see United States v. Board of School Comm'rs, 466 F.2d 573, 575-76 (7th Cir. 1972), cert. denied, 410 U.S. 909 (1973). See generally C. WRIGHT, supra note 114, §75A, at 371.

122. 249 F.2d 22 (8th Cir. 1957).

123. See id. at 28. An intervening manufacturer in Ford Motor Company's situation would likely introduce evidence as to the economic consequences of closing the tracks, in terms of loss of income, resultimg unemployment, etc., evidence to which the defendant railroad company may have no access. Such evidence is especially relevant in an equitable suit grounded in nuisance since substantive nuisance law takes into account the social costs and benefits of the challenged activity.

124. 61 F.R.D. 3 (D.V.I. 1973).

125. 506 F.2d 735 (3rd Cir. 1974).

126. Even where the challenged program was not coerced, because most of the justifications or compelling state interests that might be asserted by the defendant are in fact more accurately the direct interests of the beneficiaries, there would seem to be a difference in the intensity in interests of the beneficiaries and defendant. While it may be true that, in a given case, the defendant may have an intense ideological interest in maintenance of its race-remedial program that alone would probably be too amorphous and indefinite to be legally cognizable. Sierra Club v. Morton, 405 U.S. 727 (1972). Compare the analogous context found in Barrows v. Jackson, 346 U.S. 249 (1953), in which plaimtiff sued the white defendant for daniages caused by her sale of 
Even more significant, however, is the potential conflict between the defendant's and beneficiaries' interests demonstrated at the outset of this Comment. ${ }^{127}$ Defendant's pursuit of its parochial imstitutional concerns likely will dictate a treatinent of important issues that is opposed to the imterests of the beneflciaries. The significance of these issues to both the immediate resolution and the broader stare decisis ramifications of the case warrants a presumption of inadequate representation in the apphication of rule 24(a) to reverse discrimination suits. ${ }^{128}$

It has been argued that where the government is a party to the suit, there should be a strong presumption that representation of the absentee's interests is adequate. ${ }^{129}$ Although a number of courts have denicd intervention in various contexts expressly on that ground, ${ }^{130}$ the rule is not absolute and intervention has been allowed despite the government being a party to the litigation. ${ }^{131}$ In cases in which governmental par-

property to a nonwhite in breach of a racially restrictive covenant. Arguably, no dircct injury to any nonwhite party could have resulted from the suit since the conveyance was already completed. See id. at 267 (Vinson, C. J., dissenting). However, had an earlier action been brought to enjoin the sale, the situation presented would be closely parallel to a reverse discrimination suit. The minority prospective buyer would have a clear interest at stake. And the intcrest of the defendant seller, assuming the sale was being made at market price and other buyers were available, would have been solely ideological. Surely, rather than making the vindication of the third-party rights dependent upon the tenuousness of the imtensity of the defendant's doubtful ideological commitment, under those circumstances the court ought to have permitted the minority buycr to imtervene.

127. See text accompanying notes 20-35 supra.

128. Although it inay be contended that while the determination of factual issues as to the existence of the defendant's past discrimmatory conduct in individual cases affects the disposition of single disputes more than the making of new legal doctrine, the political value of having the issue raised adequately in the litigation cannot be overstated. This is especially true with Bakke. Becanse it is the first case to be decided on the merits by the United States Supreme Court on the question of "reverse discrimination," the ultimate disposition-i.e., whether Bakke is ordered adimited or not-is probably the most salient aspect of the case as perceived by the general public. This is especially true given the complexity of the opinion and the ambiguity of the legal theories expounded. Plaintiff victories in reverse discrimination suits, even though the opinions inay actually establish legal doctrines generally favorable to the principle of affirmative action, are likely to have a "chilling effect" as a practical inatter upon the voluntary impleinentation and maintenance of race-remedial prograins.

129. See generally C. WRIGHT, supra note 114, at 371; Note, Intervention in Government Enforcement Actions, 89 HARV. L. REv. 1174 (1976).

130. Pennsylvania v. Rizzo, 530 F.2d 501 (3rd Cir. 1976), cert. denied sub. nom. Fire Officers Union v. Pennsylvania, 426 U.S. 921 (1976); United States v. Allegheny-Ludluin Ind., Inc., 517 F.2d 826 (5th Cir. 1975), cert. denied, 425 U.S. 944 (1976); EEOC v. Umited Air Limes, Inc., 515 F.2d 946 (7th Cir. 1975); United States v. School Dist. of Oınalia, 367 F. Supp. 198, 200 n.1 (D. Neb. 1973); United States v. ITT, 349 F. Supp. 22 (D. Conn. 1972), affd mem. sub nom. Nader v. United States, 410 U.S. 919 (1973). See also C. WRIGHT \& A. MiLlER, supra note 82, at § 1909.

131. Trbovicl v. UMW, 404 U.S. 528, 537-39 (1972); Cascade Natural Gas Corp. v. El Paso Natural Gas Co., 386 U.S. 129 (1967); Bolden v. Pennsylvania State Police, 578 F.2d 912, 919-20 (3rd Cir. 1978); EEOC v. AT\&T, 506 F.2d 735 (3rd Cir. 1974); Johnson v. San Francisco Unified School Dist., 500 F.2d 349 (9th Cir. 1974); Smuck v. Hobson, 408 F.2d 175 (D.C. Cir. 1969); Association of Gen'l Contractors v. San Francisco Unified Sclrool Dist., 431 F. Supp. 854 (N.D. 
ticipation raises a strong presumption of adequacy of representation, the government typically is the plaintiff and is represented by an agency specifically charged with the duty of enforcing the particular area of substantive law. ${ }^{132}$ Hence, the presumption of adequate representation is arguably fair given the specific enforcement duties charged to and the developed expertise of the plaintiff government agency. While effective enforcement of the substantive law and the execution of carefully devised policy and strategy may militate against interference by private parties, ${ }^{133}$ it is certainly not uncommon for governmental enforcement agencies to default in their duty of representing public interests sought to be protected by the underlymg substantive law. There have been numerous instances in which welfare recipients or minority school children have had to vindicate their rights in the absence of public action by bringing private actions against the violator and/or the enforcement agency. ${ }^{134}$ And there have been instances in which the Departments of HEW and Labor received vociferous criticism for failure to enforce affirmative action policics and guidelines vigorously. ${ }^{135}$

In any event, whatever presumption operates in other contexts, there is little basis for presuming adequacy of representation in revcrse discrimination suits. The defendant may not be an entity or agency specifically charged with enforcing the substantive law that underlies the action; hence, the policy reasons for deferring, for instance, to the Justice Departinent's initiation of an antitrust action, do not apply to the defcndant state university in Bakke. But even wherc the defendant is an agency specifically cliarged with the enforcement of an affirmativc action policy, it must be acknowledged that the issue of racially preferential treatment and quotas is extremely volatile and therefore particularly sensitive to political changes affecting the policies and practices of the enforcing agency. To resolve the doubts in favor of intervention would leelp assure that the vindication of substantive legal rights is not affected by extralegal political decisions.

Moreover, the fact that the governmental body will be the defend-

Cal. 1977); Brennan v. Steamfitters, Local No. 449, 64 F.R.D. 633 (W.D. Pa. 1974); Holmes v. Government of Virgin Islands, 61 F.R.D. 3 (D.V.I. 1973); Officers for Justice v. Civil Service Comm'n, No. 73-0657 (N.D. Cal. filed Apr. 23, 1973).

132. E.g., the Department of Justice in United States v. School District of Omaha, 367 F. Supp. 198 (Neb. 1973) (school desegregation case); the Departinent of Justice in United States v. International Tel. \& Tel. Corp., 349 F. Supp. 22 (D. Conn. 1972) (antitrust case).

133. See United States v Allegheny-Ludlum Ind., Inc., 517 F.2d 826 (5th Cir. 1975).

134. Rosado v. Wyman, 397 U.S. 397 (1970); Adams v. Richardson, 480 F.2d 1159 (D.C. Cir. 1973); Brown v. Weinberger, 417 F. Supp. 1215 (D.D.C. 1976); Adams v. Weinberger, 391 F. Supp. 269 (D.D.C. I975); Linker v. Unified School Dist. No. 259, Wichita, Kan., 344 F. Supp. 1187 (D. Kan. 1972).

135. See Daily Californian, Apr. 18, 1975, at 1, col. 1; id. Apr. 14, 1975, at 3, col. 3; id. Apr.11, 1975, at 1, col. 5; id. Feb. 21, 1975, at 1, col. 4; id. Jan. 24, 1975, at 1, col. 3; id. Nov. 27, 1974, at 1 , col. 1; id. Oct. 15, 1974, at 1, col. 4; Washington Post, Sept. 24, 1978, at C7, col. 5. 
ant and not the plaintiff in reverse discrimination lawsuits is significant in two respects. First, because the government did not initiate the action there is less basis for presuming a vigorous commitment to its position in the litigation. Second, when the reverse discrimination plaintiff has a number of potential defendants from which to choose (as in the professional school admissions context), the plaintiff will prefer to name the one with the weakest ideological commitment to the program and/or the least litigation resources. Most importantly, as Bakke demonstrates, the reverse discrimination defcndant, whether it be a public or private body, may have specific institutional interests that do not coincide with the minority intervenors.

\section{Timely Application for Intervention}

Aside from the three substantive elements discussed above, rule 24(a) requires that the application for intervention be "timely." While beneficiaries clearly meet the substantive prerequisites for intervention in reverse discrimination cases, the timeliness requirement presents potential problems. Reverse discrimination suits are becoming increasingly numerous, thereby making it difficult for representatives of beneficiaries' interests to be informed of such actions. In many instances, it is conceivable that the intervenor will find out about a reverse discrimination case only after a judgment has been rendered for the plaintiff and the program invalidated. The problem is complicated to the extent that the major justification for intervention-the need to raise factual issues concerning past discrimination and biased selection procedures-necessitates that the intervenor be able to participate in all stages of the lawsuit, mcluding discovery and cross-examination at trial. Hence, intervention after a judgment has been entered practically will require a second trial, thereby substantially prejudicing the imterests of the original parties in an expedient and final adjudication. The likelihood that intervention will be denied as untimely increases dramatically as this prejudice becomes more apparent.

Tlie problem can be mitigated in a number of ways. Private mterest groups active in litigating civil rights and representing minority communities can be expected to keep a greater vigilance in monitoring the filing of reverse discrimination suits once their potential right to intervene is established. ${ }^{136}$ And as Professor Chayes points out, a number of techniques are available to the judge to solicit the representation of absentee interests at the outset of a suit, such as the utilization of indispensable parties doctrine or class action notice procedures. ${ }^{137}$

136. Indeed, there have been initial efforts in setting up a clearinghouse of attorneys specifically to facilitate participation in such lawsuits. Interview with Mark Aaronson, Director, San Francisco Lawyers' Committee for Urban Afrairs, in San Francisco, California (Jan. 22, 1979).

137. Chayes, supra note 63 , at 1311-12. 
Moreover, while intervention after judginent is unusual, nonetheless it should be granted where it is the only way to protect the intervenor's rights. ${ }^{138}$ The length of the delay is only one factor the court considers and taken alone cannot be dispositive to a rule 24(a) motion. Courts have placed great emphasis on equitable considerations. Where the potential intervenors knew or reasonably should have known long before making the rule 24(a) motion that their rights were in jeopardy, intervention may appropriately be denied. ${ }^{139}$ Unless such equities weigh heavily agamst minority intervenors in a particular suit, the timeliness requirement ought to be apphed hiberally to permit late intervention.

\section{Intervention in Foward Discrimination Suits Compared}

Minority beneficiaries meet all the theoretical requirements of rule 24(a) to intervene as a matter of right in reverse discrimination lawsuits. Thus, the courts should have little problem with accommodating the general justifications for beneficiary intervention within doctrinal himits of the rule. Although there have been no pubhshed cases directly on point to serve as precedent, intervention by similarly affected whites has been allowed in the converse context of forward discrimination lawsuits.

In $E E O C$ v. $A T \& T,{ }^{140}$ where a settlement had been worked out between the EEOC and the defendant employer which called for the establishment of an affirmative action quota in hiring and promotion, a union, representing potentially adversely affected white workers, was granted intervention since the settlement jeopardized and conflicted with certain terms (for exainple, seniority provisions) of its collective bargaining agreement. Similarly, in Kirkland v. New York State Department of Correctional Services, ${ }^{141}$ nonminority officers, otherwise eligible for proinotion, were allowed to intervene in a discrimination suit brought by mimorities seeking a decree ordering the development of vahd employment tests and the imposition of racial quotas in promotions. ${ }^{142}$

138. See EEOC v. AT\&T, 506 F.2d 735 (3rd Cir. 1975); Pelligrino v. Nesbit, 203 F.2d 463 (9th Cir. 1953); United States v. Allegheny-Ludlum Indus., Inc., 63 F.R.D. 1 (N.D. Ala. 1974), aff'd 517 F.2d 826 (5th Cir. 1975), cert. denied, 425 U.S. 944 (1976). See generally 3 MOORE'S Federal. Practice f 24.13(1), at 24-521-22 (2d ed. 1978).

139. SEC v. Bloomberg, 299 F.2d 315 (1st Cir. 1962); EEOC v. AT\&T, 365 F. Supp. 1105 (E.D. Pa. 1973), affd in part and rev'd in part, 506 F.2d 735 (3rd Cir. 1975); Alaniz v. California Processors, Inc., 73 F.R.D. 269 (N.D. Cal. 1976); Bolden v. Pennsylvania State Police, 16 F.E.P. 285 (E.D. Pa. 1977), aff'd in part and rev'd in part, 578 F.2d 912 (3rd Cir. 1978). See also Kirkland v. New York State Dept. of Correctional Serv., 520 F.2d 420, 424 (2d Cir. 1975).

140. 506 F.2d 735 (3rd Cir. 1974).

141. 520 F.2d 420 (2d Cir. 1975).

142. Although the white officers were allowed intervention, the court rejected tlyeir motion for dismissal for nonjoinder of themselves at the outset as indispensable parties. See also Patterson v. Newspapers \& Mail Deliverers' Union, 514 F.2d 767 (2d Cir. 1975), cert. denied sub nom. Larkin v. Patterson, 427 U.S. 911 (1976). 
Note that whites who are affected or displaced by a decree in forward discrimination suits brought by minorities charging invidious discrimination are placed in a situation similar to affirmative action beneficiaries in reverse discrimination suits. For instance, a prospective nonminority job applicant or candidate for promotion has a material stake and a colorable legal interest in having that stake allocated in a race-neutral fashion. Where the court decrees a race-preferential reinedy, the affected white einployee's or apphicant's ability to protect his or her interest is impaired. ${ }^{143}$

Reverse and forward discrimination lawsuits are not entirely syminetrical, however, with respect to the issue of adequaey of representation. The issues of past discrimination on the defendant employer's part and biased selection criteria have no counterpart in the forward discrimination suit since the doctrines pertaining to the remedial and coinpensatory uses of race are relevant only in the reverse discrimination context. Thus there will be no failure to hitigate such important and relevant issues by the origmal parties in the forward discrimmation context. Moreover, the presence of antidiscriminatory laws and political pressure have in many instances resulted in the effectively involuntary establishment of affirmative action programs by schools and einployers, thus giving rise to at least the suspicion, and perhaps presumption, of inadequate representation by such defendants of the interest of minorities in reverse discrimination suits. In the forward discrimination case, the defendant's challenged conduct is not likely to have been externally coerced (smce there are, of course, no laws requir-

143. Indeed, that impairment may be severe. Courts have held that a suit challenging a quota decreed as a remedy in a forward discrimination lawsuit constitutes an impermissible collateral attack on a previous judgment. In Prate v. Freedman, 430 F. Supp. 1373 (W.D.N.Y. 1977), cert. denied, $98 \mathrm{~S}$. Ct. 2274 (1978), white police officers sued the city for its settlement of a discrimination suit brought by mmorities which mandated an affirmative action program. In noting that timely intervention would have been granted in the earlier discrimination case, the court held this subsequent suit cIaiming discrimination from affirmative action policies constituted an imperınissible collateral attack on the ruling in the prior case. See also O'Burn v. Shapp, 70 F.R.D. 549 (E.D. Pa. 1974), affd without opinion, 546 F.2d 418 (3rd Cir. 1975), cert. denied, 430 U.S. 968 (1977); Construction Indus. Comb. Comm. v. International Union of Operating Engineers, 67 F.R.D. 664 (E.D. Mo. 1975). Although this loolding seens contrary to the fundamental due process tenet that no person can be legally bound to an action to which he is not a party, BlonderTongue v. University of Ill. Foundation, 402 U.S. 313, 329 (1971), possible authority can be found in Justice Harlan's mtimation im Provident Tradesinens Bank \& Trust Co. v. Patterson, 390 U.S. 102,114 (1968), that a party can be bound if one with an adequate opportunity to intervene purposely refused to so participate. Where all the members of the affected class have actual notice of the action and choose to sit on their rights, estopping them in a subsequent collateral action does not seem unjust. See In re Four Seasons Sec. Laws Litigation, 502 F.2d 834, 842-43 (10th Cir. 1974). Thus these cases should only be applicable where the affected class is sinall and individual notice is therefore feasible. Where the potential class is innumerable and unidentifiable and individual notice therefore impracticable, as in the case of professional school affirmative action beneficiaries, binding the class for failure to intervene is improper. 
ing discrimination), and hence, there is no reason to believe that the defendant will not assert a vigorous defense.

Since the courts accordingly are likely to require a lesser showing of inadequacy of representation by intervenors in reverse than in forward discrimination suits, intervention in reverse discrimination lawsuits should be allowed even where it would not be appropriate in forward discrimination suits. ${ }^{144}$

\section{B. Joinder by Indispensable Parties Under Rule 19(a)}

From the perspective of minority beneficiaries, the joinder of indispensable parties under rule 19(a) is the most attractive procedural device for assuring their participation in reverse discrimination litigation. That rule provides:

A person . . . shall be joined as a party in the action if . . (2) he claims an interest relating to the subject of the action and is so situated that the disposition of the action in his absence may (i) as a practical unatter inpair or impede his ability to protect that interest or (ii) leave any of the persons already parties subject to a substantial risk of incurring double, multiple, or otherwise inconsistent obligations by reason of his claimed interests. If he has not been so joined, the court shall order that he be made a party.

It is clear from both the language and the advisory committee notes that rule $19(\mathrm{a})(2)$ and rule $24(\mathrm{a})(2)$ were meant to dovetail. ${ }^{145}$ The elements of having an interest in the litigation and a practical impainnent of the ability to protect that interest are almost identically stated.

Although satisfaction of those elements under rule 24(a) would seein to dictate that joinder is required under rule 19(a), the D.C. Circuit has stated that "the fact that the two rules are entwined does not imply that an 'interest' for the purpose of one is precisely the saine as

144. Intervention by whites has been denied in foward discrimination lawsuits either because of a failure to show inadequate representation of their interests by the defendant or excessive untimeliness in filing the rule 24(a) application. See Bolden v. Pennsylvania State Police, 578 F.2d 912 (3rd Cir. 1978) (order denying intervention by class of nonminority job applicants vacated and remanded for consideration of whether their interests were adequately represented by existing parties); Pennsylvania v. Rizzo, 530 F.2d 501 (3rd Cir. 1976); Alaniz v. Cahfornia Processors, Inc., 73 F.R.D. 289 (N.D. Cal. 1976), affd, 572 F.2d 657 (9th Cir. 1978); Chance v. Board of Examiners, 51 F.R.D. 156 (S.D.N.Y. 1970).

145. The Advisory Committee's Note to rule 24(a) states that "[i]ntervention of right is here seen to be a kind of counterpart of Rule 19(a)(2)(i) on joinder of persons needed for just adjudication," and that "[t]he amendment provides that an applicant is entitled to intervene in an action where his position is comparable to that of a person under Rule 19(a)(2)(i), as amended, unless his interest is already adequately represented in the action by existing parties." See Atlantis Dev. Corp. v. United States, 379 F.2d 818, 825 (5th Cir. 1967): "Although this is question-begging and is therefore not a real test, this approacli shows that the question of whether an intervention as a matter of right exists often turns on the unstated question of whether joinder of the intervenor was called for under new Rule 19." 
for the other," 146 and that the occasions for intervention under rule 24 are broader than for joinder under rule 19. The practice has generally been in accordance with this statement. ${ }^{197}$

Nevertheless, the requirements for joinder under rule 19(a) are inet in reverse discrimination suits. Cases requiring joinder of parties under the rule frequently involve coinpeting claimants to a common fund. ${ }^{148}$ As has been shown, ${ }^{149}$ the common fund cases are analogous to reverse discrimination lawsuits in which the plaintiff and future minority applicants to the challenged affirmative action prograin are coinpeting claimants to the limited number of employinent or admissions positions available at any particular point in time.

Moreover, joinder of the minority beneficiaries would be appropriate from the perspective of the defendant in a reverse discrimination suit. Rule 19(a)(2)(ii) provides for the joinder of an absentee party where disposition of the action may "leave any of the persons already parties subject to a substantial risk of incurring inconsistent obligations." The scissoring effect of reverse discrimination suits by whites on one side and forward discrimination suits by minorities on the other potentially forces the einployer or university to walk a "tightrope" of legal liability. It is not inconceivable that a reverse discrimination defendant losing to a white plaintiff might, upon the disinantling of the affirmative action program, be successfully sued by mimorities claiming that the resulting selection process is racially biased and unlawful. ${ }^{150}$ This is precisely the type of inconsistent obligation which joinder under rule 19 (a)(2)(ii) is designed to prevent. ${ }^{151}$ The problem can be unitigated by joining the class of minority beneficiaries to fully litigate the issues of past discrimination and biased admissions or hiring criteria.

146. Smuck v. Hobson, 408 F.2d 175, 178 (D.C. Cir. 1969).

147. In Kirkland v. New York State Dept. of Correctional Serv., 520 F.2d 420 (2d Cir. 1975), the court allowed the white officers' claim for dismissal for nonjoimder of indispensable parties in a successful forward discrimination suit brought by minority officers, even though those white officers had been allowed to intervene. Cases in which white plaintiffs' claim of reverse discrimination was dismissed as an impermissible attack on an earlier judgment in a forward discrimination suit have indicated that the proper procedure would have been to intervene in the earlier lawsuit. The courts never suggest, however, that their joinder was required to render the previous judgment valid. See note 143 supra.

148. See, e.g., Haas v. Jefferson Nat'l Bank, 442 F.2d 394 (5th Cir. 1971).

149. See text accompanying note 89 supra.

150. Conversely, a defendant, successfully sued for invidious discrimination and ordered to implement a race-remedial quota, might subsequently be sued for reverse diserimination. However, an inconsistent result would be highly unlikely in that instance given that courts have held such actions to be an impermissible collateral attack on the initial decree, see note $143 \mathrm{supra}$, and since the use of quotas as a remedy to a judicial finding of discrimination appears valid under Bakke. However, if the quota were instituted as a result of a settlement without completed hitigation and there is no specific admission of the defendant's guilt, it is unclear whether the defendant will be shielded from reverse discrimination claims and lience, subject to conflicting obligations.

151. Note in addition that the defendant may face double liability if the plaintiffs in the successive suits are awarded damages as well as injunctive and declaratory relief. 
Having been joined in the initial reverse discrimination suit, minority beneficiaries would be prevented by principles of res judicata from instituting a subsequent forward discrimination action. ${ }^{\text {is2 }}$

The indispensable party doctrine is an especially attractive vehicle for beneficiary participation because it places the onus upon the court and existing parties to bring the beneficiaries into the action. ${ }^{153}$ The administrative burdens that would be created make it unlikely, however, that the courts would be anxious to extend the applicability of rule 19 to the context of reverse discrimination litigation. For instance, it nnay be difficult for the courts to identify the potential applicants to the affirmative action program who should be joined. Even so, such administrative problems are not insurinountable and should not constitute grounds for refusing joinder under rule 19. As a general matter, the courts are most competent in their role of resolving problems of judicial procedure and manageinent. For instance, a court, in the exercise of its equitable discretion, could require the defendant to supply a hist of current minority applicants potentially affected or publish notice of the pending action in order to solicit a response froin potential indispensable parties. The court unight even appoint a guardian ad litem to

152. The class action procedure would presumably be brought under rule 23(b)(1) which governs actions in which

the prosecution of separate actions by or against individual members of the class would create a risk of $(A)$ inconsistent or varying adjudications with respect to individual members of the class which would establish incoinpatible standards of conduct for the party opposing the class, or (B) adjudications with respect to individual members of the class which would as a practical matter be dispositive of the interests of the other inembers not parties to the adjudications or substantially impair or impede their ability to protect their interests.

This is the section that counterparts joinder under rule 19(a). See Advisory Committee Note to the 1966 amendment to rule 23. Although notice to members of the class is required by subdivision (c)(2) in (b)(3) class actions, the rule does not mandate notice in (b)(1) actions. Thus jomder of the class of beneficiaries under rule $23(\mathrm{~b})(1)$ is likely to be binding on the entire class regardless of individual notification, provided that the class is deemed adequately represented. However, subsection (d)(2), apphicable to all class actions brought under rule 23 generally, authorizes the court, in its discretion, to:

make appropriate orders . . . (2) requiring, for the protection of members of the class or otherwise for the fair conduct of the action, that notice be given in such manner as the court may direct to some or all of the meinbers of any step in the action, or of the proposed extent of the judgment, or of the opportunity of members to signify whether they consider the representation fair and adequate, to imtervene and present claims or defenses, or otherwise to come into the action.

In view of the importance of the stake and expansive ramifications of reverse discrimination litigation, the complexity of the legal and factual issues involved, and the potential multiplicity of viewpoints held among various beneficiaries having distinct interests (such as those of potential medical school minority applicants, practicing minority professionals, service recipients in minority cominunities, members of different racial groups within the class of beneficiaries, etc.), the courts should exercise their discretion hberally in favor of giving notice to as many members of the class as is practicable.

153. The Advisory Committee's Note to the 1966 amendinent to rule 19 states that "A person may be added as a party at any stage of the action on motion or on the court's imitiative (See Rule 21)." 
represent the class of beneficiaries. ${ }^{154}$ In assuring that the chosen party adequately represents mimority beneficiaries the court can utilize class action practices under rule $23 .{ }^{155}$ The substantive and procedural standards that have evolved in regard to that requirement can easily be adopted into the rule 19 context. Indeed, the standards of rule 23 will apply directly where the court decides to join beneficiaries as a class im order to preclude potential forward discrimmation suits.

In short, although the application of rule 19's imdispensable party doctrine to minority beneficiaries in reverse discrimmation suits would represent a substantial innovation, there is no reason why the courts could not make this step were they so mclined.

\section{CONCLUSION}

Reverse discrimination litigation poses a number of ironies. In most cases, a white plaintiff and a white-dominated mstitutional defendant are litigatimg the rights of unrepresented minority groups. In sucl litigation, while the legal and material stakes are extraordinarily high, the integrity and effectiveness of the adjudicatory process are inlierently impaired. This Cominent demonstrates that there are compelling political, jurisprudential, and constitutional considerations that mandate the systematie and full participation of minority beneficiaries in lawsuits in which race-conscious affirnative action prograins are challenged. Although effecting procedural justice and safeguarding the imtegrity of the litigation structure cannot assure the attainment of just and correct substantive outcomes, the forner are indispensable to the latter.

The Federal Rules of Civil Procedure readily provide feasible means of facilitatimg beneficiary participation. The context of reverse discrimination lawsuits easily fits within the doctrinal contours of intervention as of right under rule 24(a) and joinder of necessary parties under rule 19(a). ${ }^{156}$ Coupling the availability of existing procedures

154. See Chayes, supra note 63, at 1311-12.

155. Rule 23(a)(4) requires as a prerequisite to all class actions that "the respective parties will fairly and adequately protect the interests of the class." See $1 \mathrm{H}$. Newburg, Class Actions $\S 1120$ at 195 (1977); C. Wright \& A. Miller, Manual of Complex Litigation 30-33, supra note 82 (Supp. 1973); Note, Developments in the Law-Class Actions, 89 HARv. L. Rev. 1318, 1475-89 (1976).

156. The Federal Rules of Civil Procedure also provide other ineans of participation. If beneficiaries have the right to intervene under rule 24(a), they should be granted permissive intervention under rule 24(b), which provides that the court shall have discretion to allow intervention "when an applicant's claim or defense and the inain action have a question of law or fact in common." The identical material stake at controversy counmon to the claims of the beneficiaries and original parties as well as the doctrinal nexus between the remedial use of race and the issue of past discrimination provide the requisite intertwining of law and fact. Permissive intervention is, however, a less attractive alternative since its availability lies within the sound discretion of the trial court subject to a mininal scope of review on appeal. C. WRIGHT, supra note 114, at 374 . 
with its equitable powers, the courts can and should fashion fair and effective procedures in ensuring the participation of minority beneficiaries.

Edward Chen*

Moreover, the court may limit the manner and scope of the intervenor's participation. See Van Hoomissen v. Xerox Corp., 497 F.2d 180, 181 (9th Cir. 1974); Ionian Shipping Co. v. British Law Ins. Co., 426 F.2d 186, I91-92 (2d Cir. 1970); United States v. American Inst. of Real Estate Appraisers, 442 F. Supp. 1072, 1083 (N.D. Ill. 1977).

Minorities inight also bring a foward discrimination suit against the reverse-discrimmation defendant charging past discrimination or biased regular selection procedures and then move to consolidate the actions for trial under rule $42(\mathrm{a})$, which affords the court broad discretion to consolidate different actions when they involve a "common question of law or fact." See C. WRIGHT, supra note 114, at 483 .

* B.A. 1975, University of California, Berkeley; third-year student, Boalt Hall School of Law. 
